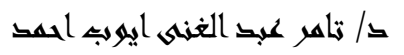

$$
\begin{aligned}
& \text { العوائد البترولية وأثرها على التتمية الاقتصادية }
\end{aligned}
$$

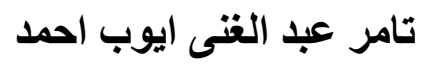

$$
\begin{aligned}
& \text { تحت اشر اف افت التوب } \\
& \text { الأستاذ الدكتور } \\
& \text { أحمد ماهر عز الاذ الاكتور } \\
& \text { أستاذ الإقتصاد و المالية العامة }
\end{aligned}
$$

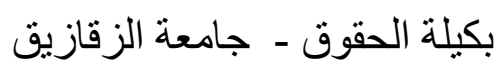

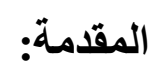

مما لاشك فيه بأن العائدات البترولية تحنل أهمية كبيرة بالنسبة للإقتصادات المتقدمة و النامية على حد سو اء وكذلك الحالى بالنسبة لكلا الدول المنتجة و المستهلكة.

- فالدول المنتجة تتحصل عليها وتساهم بها فى تمويل موازنتها العامة وبهذا

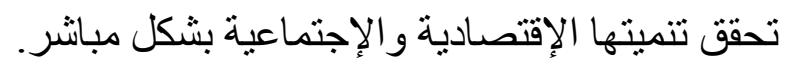

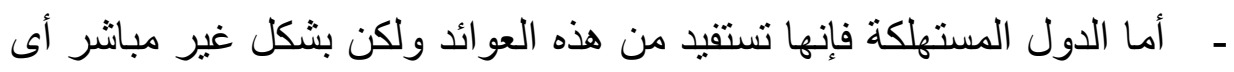

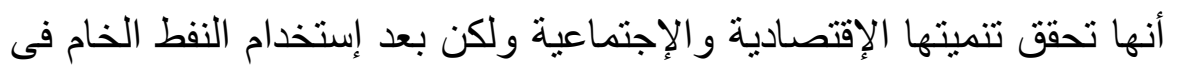
إنتاج السلع و الخدمات التى تساهم فى تحقيق تلإك التنمية.

و الو اقع بأن العائدات البترولية تمثل نسبة كبيرة فى الإقتصاديات النفطية وخصوصاً

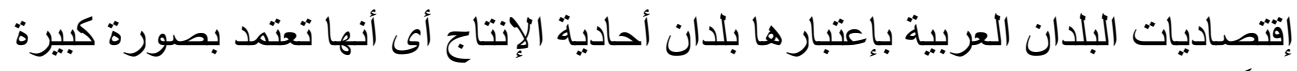

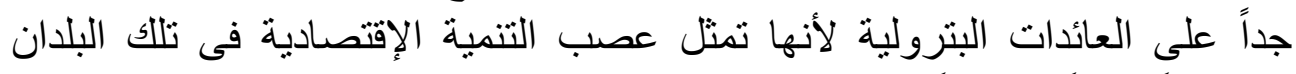

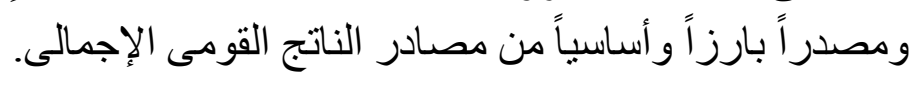

مشكلة البحث:

كيفية توجيه هذه العوائد البترولية الحالية وتعظيمها فى مشروعات مستقبلية تعود بالنفع على الإقتصاد القومى للدول المنتجة حيلا إنخفاض هذه العو الذهائد.

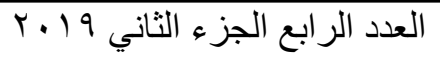

المجلد العاشر 


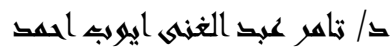

\section{أهمية البحث:}

إن البترول يشمل العنصر الرئيسى فى بناء قاعدة صناعية وخاصة صناعة التكرير

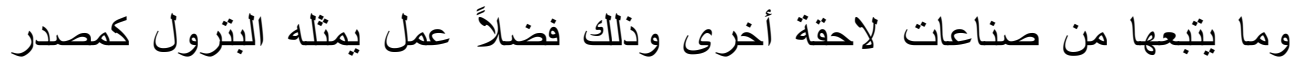
لإمدادت الطاقة.

وتعتمد أغلب الدول المنتجة للبترول على البترول فى تمويل إقتصادياتها وذللك لما يتمتع به النفط من مز ايا إيجابية كبيرة.

ولكنه فى نفس الوقت يتسم تبذبذب أسعاره بين الحين و الأخر مما يؤثر على مستوى

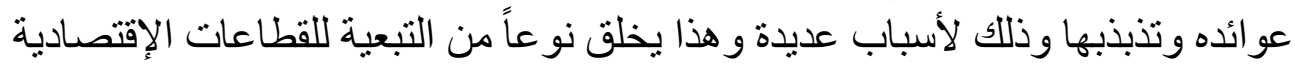

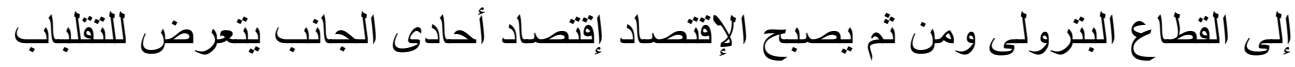
التى تصيب القطاع البترولى.

وكما هو الحال بالنسبة للدول العربية البترولية التى تعرضت له عندما واجهت تحدياً حقيقياً يمس أساس وجودها والذى يتمثل فى تأكل قاعدتها المادية من العو ائد البترولية

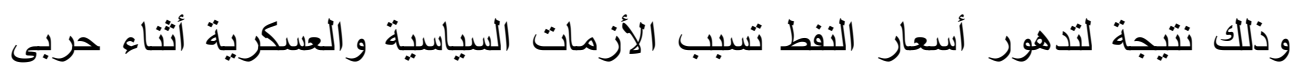

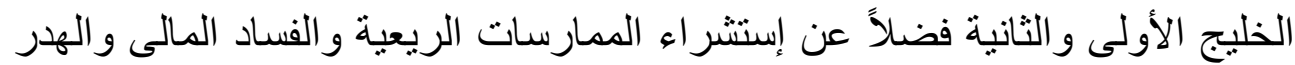

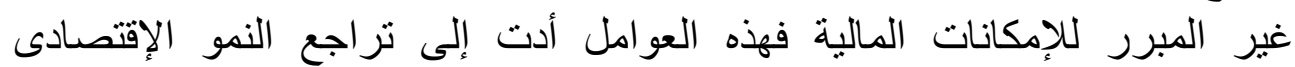
ومعدلات التكوين الر أسمالى وسوء توزيع الثروة بين الأفراد.

ونتيجة لما سبق فإن العائدات البترولية لها أثار ها الإيجابية و أخرى السلبية وهذه الأثار

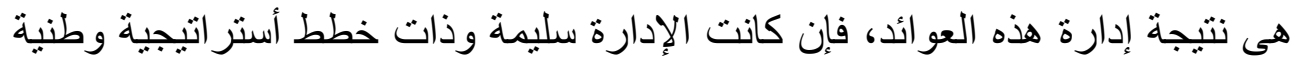

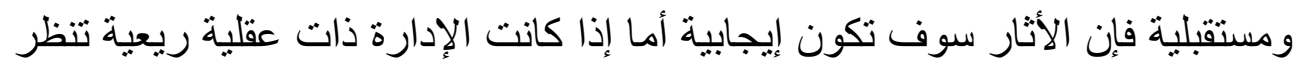

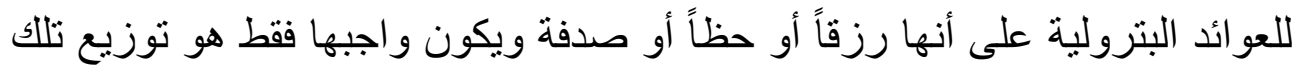
العوائد على المواطنين فهى بذلك عملت على قطع العلاقة بين تيار العوائد البترولية

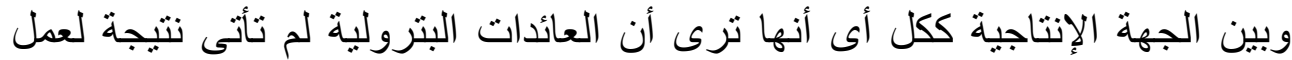
إنسانى منظم ينتج عن الجهة أو تحمل المخاطر.

العدد الرابع الجزء الثاني 9 ب ب

المجلد العاشر 


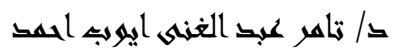

و هذا ما أشنار إليه لوشيانى حيث قال ( إن الصفة الأساسية للعقلية الريعية هى إنها

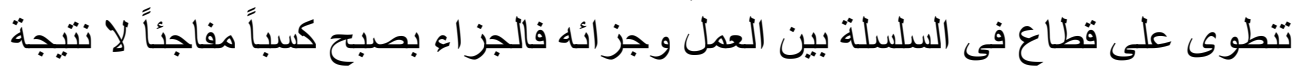

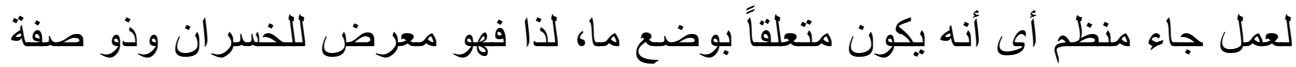
نهازة للفرص. أهداف البحث: - 2 - 2

العائدات النفطية هى المردودات النقدية التى تحصل عليها الدول البترولية مقابل

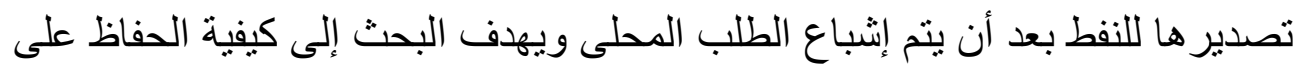
تلك العو ائد وأستثمار ها فى مجالات ناحجة لتعظيم تلك العو ائد من خلال كيفية التعامل

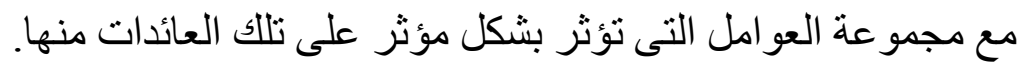

\section{1- (أسعار النفط}

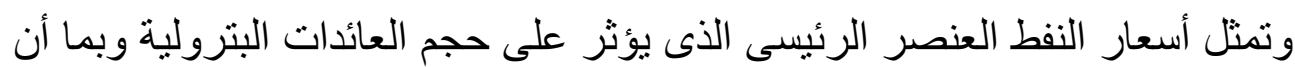

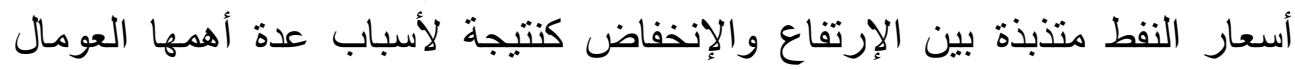

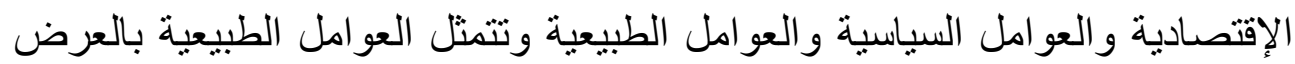

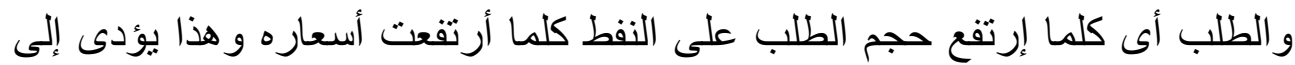

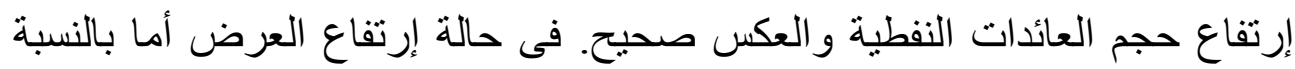

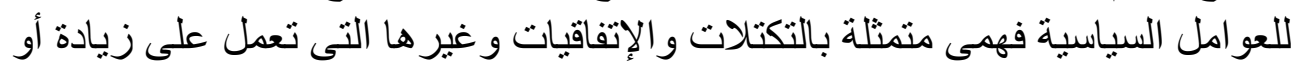

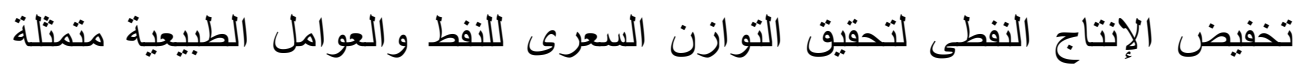

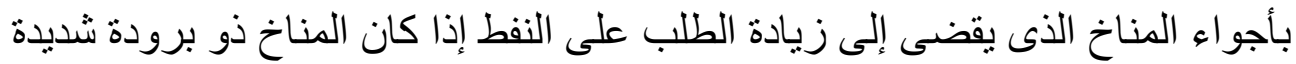

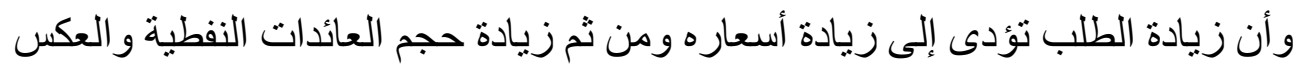
صحيح فى حالة إعتدال هذا المناخ.

\section{r - بم الإحتياطى النفطى}

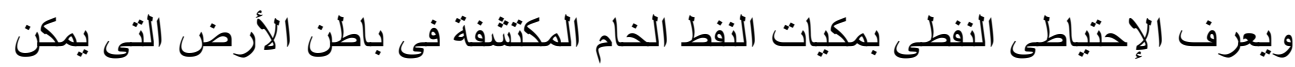
إستخر اجها بالثكل الإقتصادى وبالأدوات المتاحة فكلما تتوفر الإحتياطات النفطية 


\section{العوائي البتخرولية وأثرها علىى التنمية الاثتماكية}

د/ تاهر عبد الغنهى ايهوبه امهد

بشكل كبير كلما ساعدت تللك الإحتياجات على الإنتاج بشكل كبير وذللك بعد الإهتمام

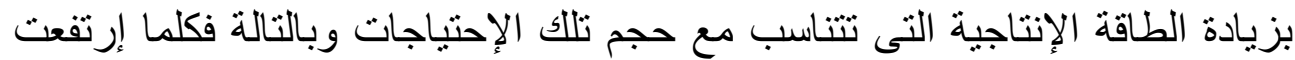
الإحتياطات النفطية أدت إلى زيادة الإهتمام بزيادة الطاقة الإنتاجية وزيادة الإنية الإنتاج

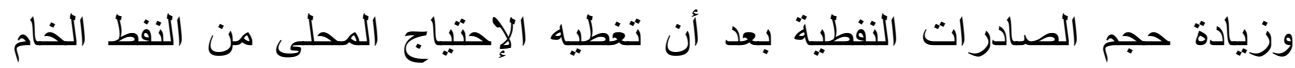
وبالتالى زيادة حجم العائدات البترولية.

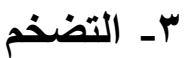

يعرف التضخم على أنه الإرتفاع العام والمتسمر فى أسعار السلع و الخدامت وبما أن

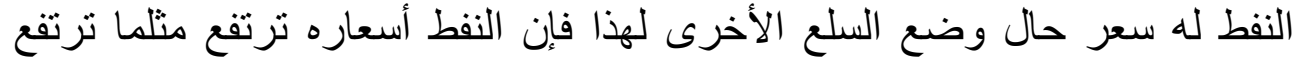
أسعار السلع الأخرى وبالتالى فإن التضخم يؤثر الأن على حجم العائدات البترولية إذا أنها

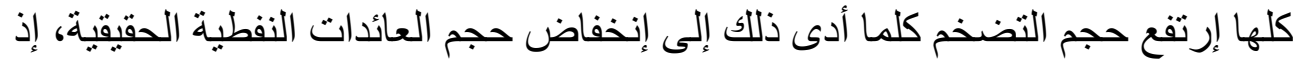
أن العائدات النفطية قبل إرتفاع حجم التضخم مع إفتر اض بقاء العو امل الأخرى ثابته كحجم الإنتاج وحجم التصدير كانت ذات قدرة وقوة شر ائية فعلى على سبيل المثنال فقد إنداء كانت العائدات النفطية قبل إرتفاع حجم التضخم تؤدى إلى إنجاز أغلب المشاريع

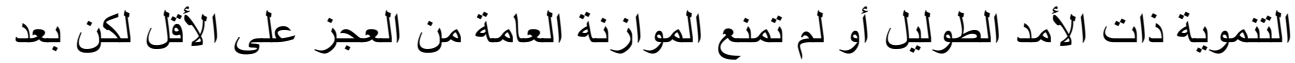

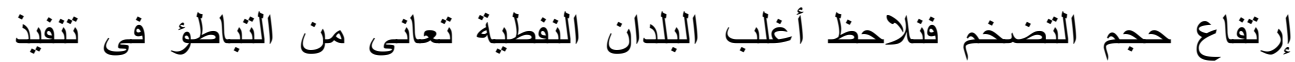

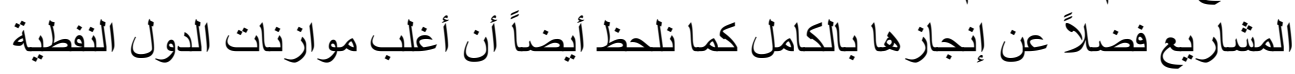
تعانى من العجز وذلك بسبب إعتمادها على النفط بشكل كبير جداً المتميز بتذبذب التبات التها

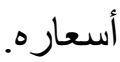

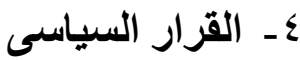

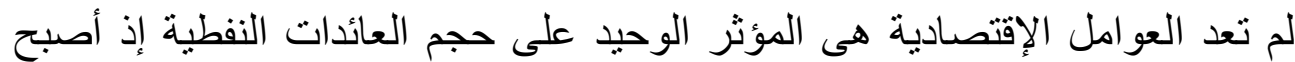
القرار السياسى لا يقل أهمية عن العومال الإقتصادية فى التأثير على عجى حجم العائدات

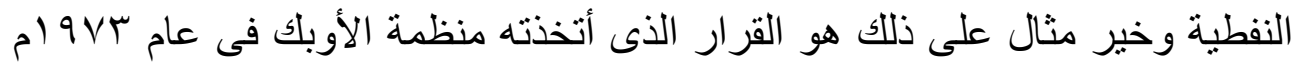
فى منع تصدير النفط إلى جميع الدول التى ساندت العدوان الإسر ائيلى على فلسطين

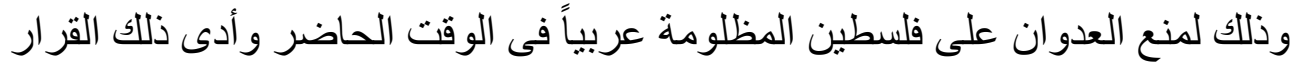




\section{العوائي البتخرولية وأثرها علىى التنمية الاثتماكية}

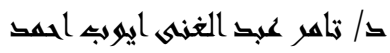

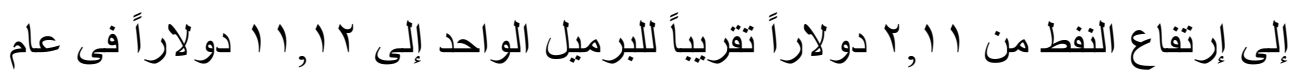
9 ا م وكذلك بالنسبة للحرب العر اقية الإير انية.

0ـ - الفساد المالى والإدارى

إن من أهم التحديات التى تو اجه البلدان النفطية فى الوقت الحضـار هى مشكلة الفساد

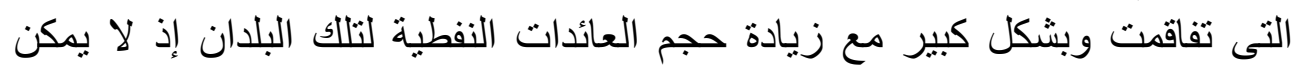

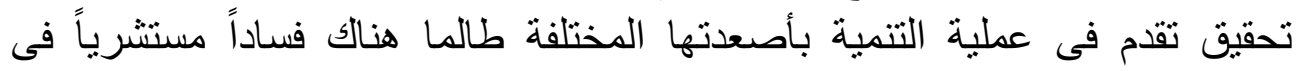
القطاعات الإقتصادية فعن طريق الفساد يتم هدر وتبذير العائدات النفطية مما بهدد

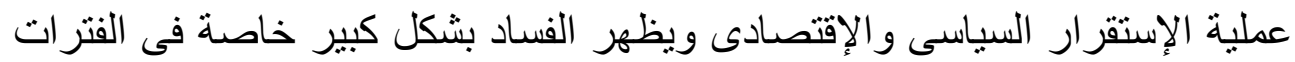

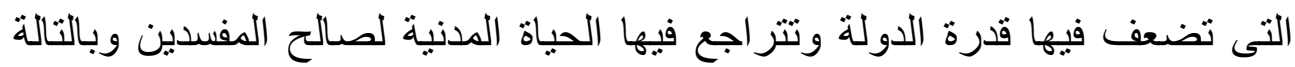
يكون الفساد الصفة اللازمة للاولة والمجتمع حيث تتمثل معظم حالات الفساد بتوزيع

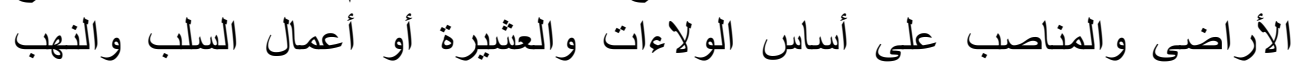

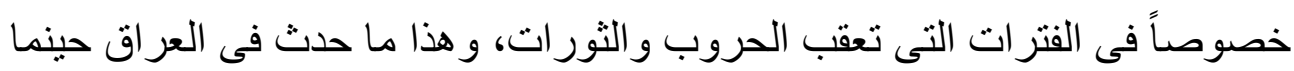

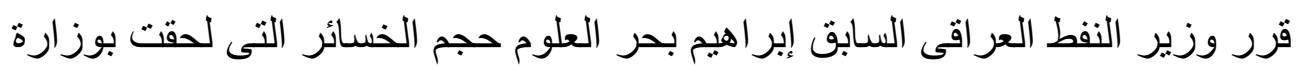

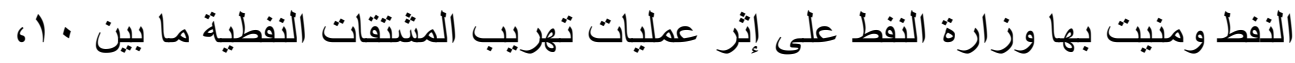

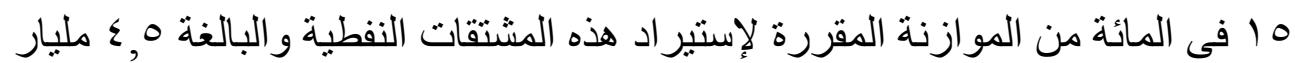
دولار.

\section{منهج البحث:}

يعتمد هذا البحث على المنهج الوصفى التحليلى الذى يصف الحقائق والوقائع و الأحداث و التجارب مما يقوم على در اسة وتحليل الابحاث و البيانات و الإحصائيات

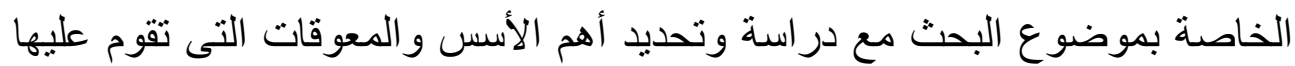
الأساليب المقترحة. بموصوع. 
تقوم فكرة البحث على إبراز الدور الكبير للعائدات البترولية وما تقدمه من توافر

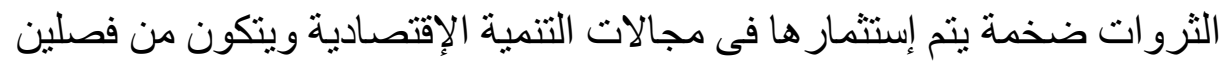
الفصل الأول: طبيعة التنمية الإقتصادية. الفصل الثانى: الإستثمار الأجنبى فى مجال الصناعات النفطية و أثره على تعظيم العو ائد.

\section{الفصل الأول \\ طبيعة التتمية الاقتصادية الاولة}

تعتبر التتمية(') الاقتصادية أهم الأهداف الاساسية التي تسعى خلفها

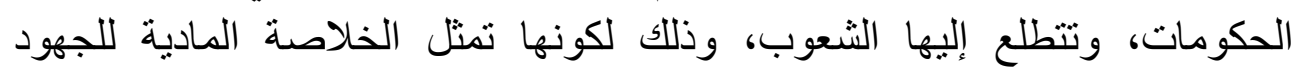

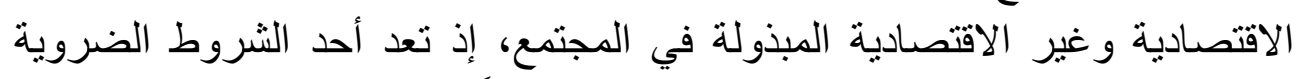

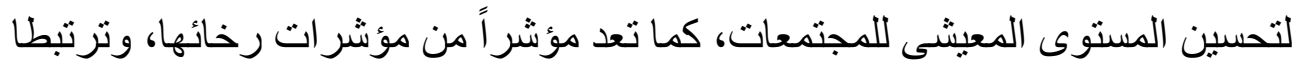

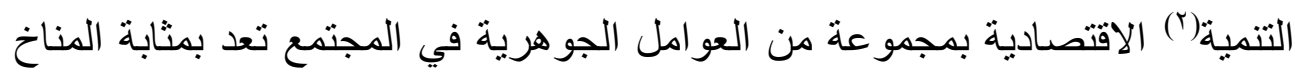

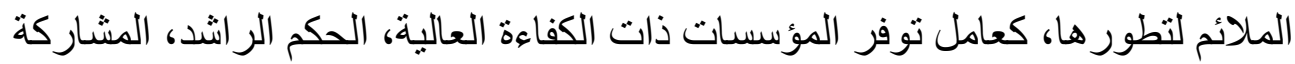
المجتمعية، البحث العلمى، الصحة و التعليم وسوف يتم تناول هذا المبحث كالتالى: ثانياً: أهداف التنمية الاقتصادية. أولاً: ماهية التنمية الاقتصادية. رابعاً: متطلبات التتمية الاقتصادية.

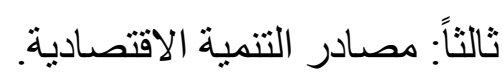
خامساً: استر اتيجية وأساليب التنمية الاقتصادية. سادساً: معوقات التنمية الاقتصادية. أولاً: ماهية التنمية الاقتصادية: يعد مفهوم التتمية من أهم المفاهيم العالمية في القرن العثرين، حيث أطلقت

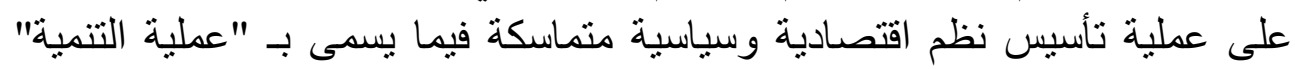


ويشير المفهوم لهذا التحول بعد الاستقلال - في الستينات من هذا القرن - في آسيا

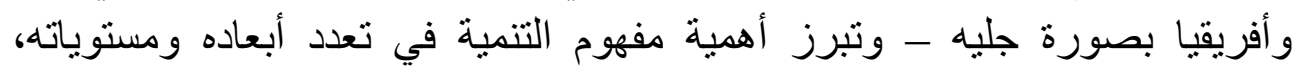

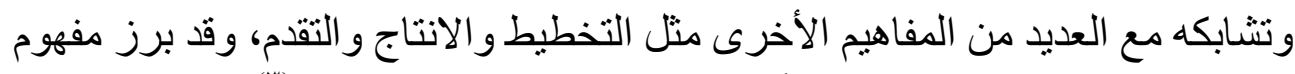
التنمية Development بصورة أساسية منذ الحرب العالمية الثانية(").

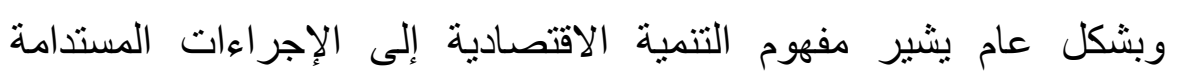

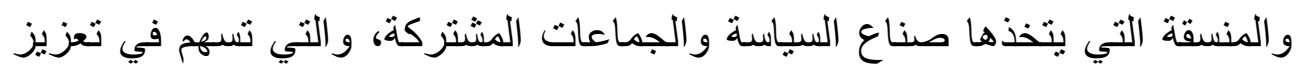

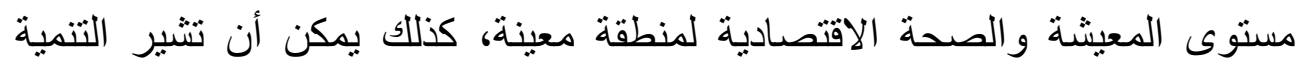

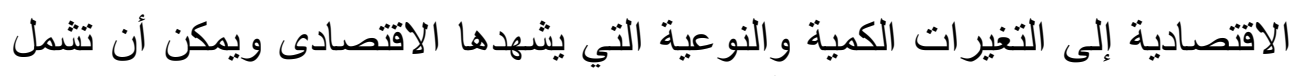

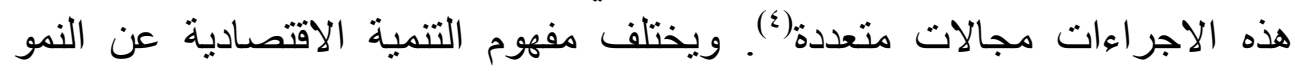

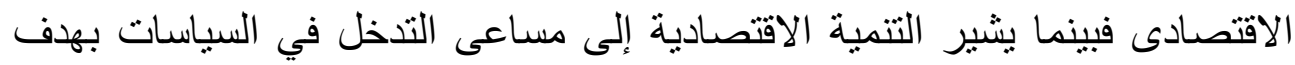

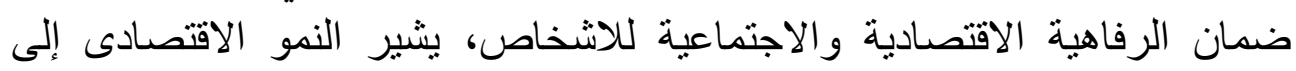

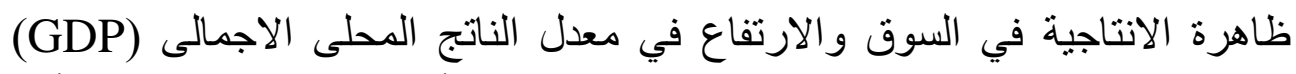

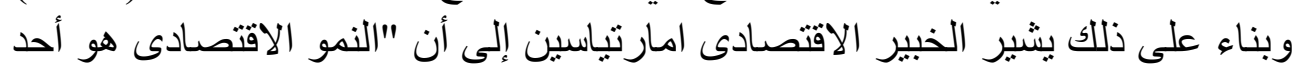
جو انب عملية التنمية الاقتصادية" (o).

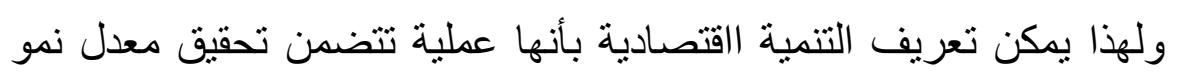

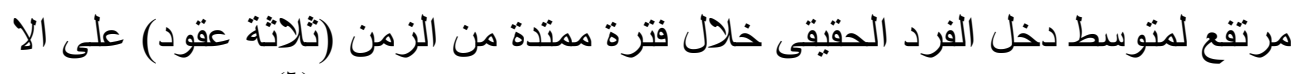

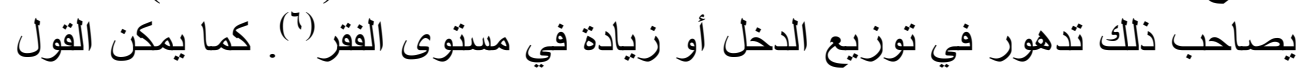

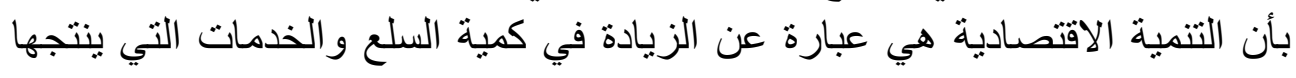

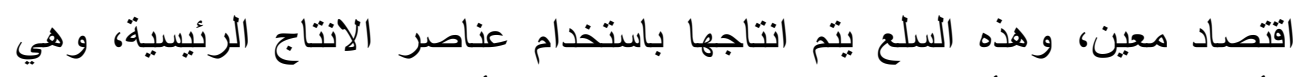

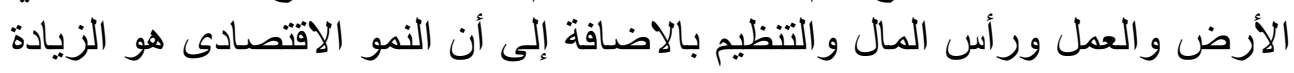

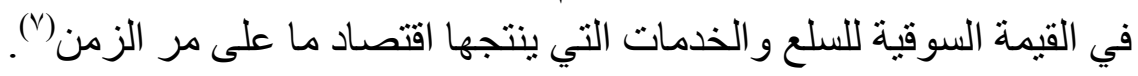
و لا شك أن للتنمية الاقتصادية العديد من المتطلبات منها: ا ب. التخطيط وتوفير البيانات و المعلومات اللاشعة. r. الانتاج بجودة وتوفير التكنولوجيا الملائمة لتوفير الموارد البشرية المتخصصئة

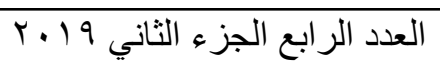




\section{العوائي البتخرولية وأثرها علىى التنمية الاثتماكية}

د/ تاهر عبق الغنهى ايوبه الممك

$$
\text { ع. ـ. توفير الأمن و الاستقر ار اللازمين. الاقتصادية الملائمة. }
$$

ويعتبر أهم متطلب من متطلبات التتمية الاقتصادية(^) العدالة الاجتماعية حيث

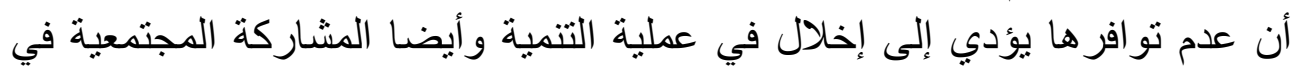
عملية التنمية وذلك باثر اف المجتمع في قراري إتى في ات التمية وذلك لزيادة تقبل المجتمع للتغير نحو التنمية الاقتصادية.

\section{ثاتياً: أهداف التتمية الاقتصادية:}

للتنمية الاقتصادية أهداف عديدة تدور كلها حول رفع معيشة السكان توفير

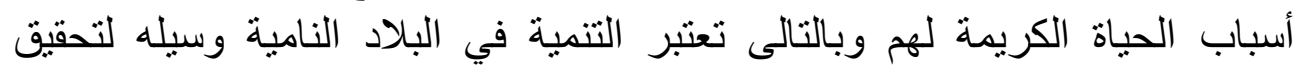

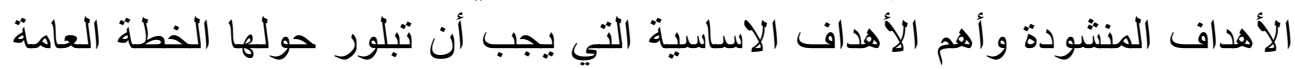
للتنمية الاقتصادية في ايران هي:

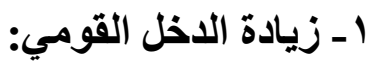

حيث يعتبر زيادة الدخل القومى أهم أهداف التتمية الاقتصادية في الدول

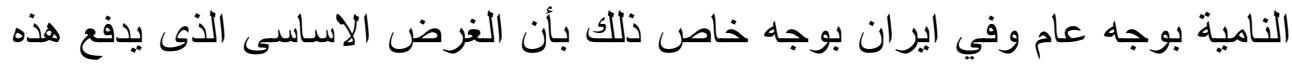

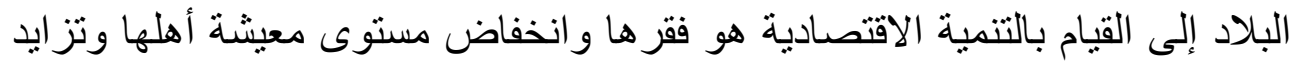
نمو عدد سكانها(9) ولا سبيل للقضاء على كل الأل هذه المشاكل سوى زيادة الدخل

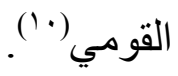

\section{r ب - رفع مستوى المعيشة:}

يعتبر تحقيق مستوى المعيشه من بين الأهداف العامة التي تسعى إلبها دولة

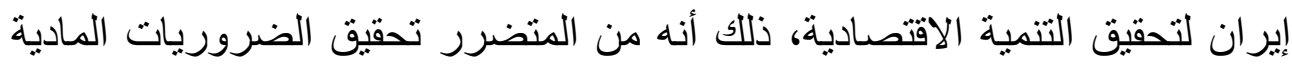
للحياة وتحقيق مستوى ملائم للصحة والثقافة ما لم يرتفع مستوى معيثة السكان 


\section{العوائي البتخرولية وأثرها علىى التنمية الاثتماكية}

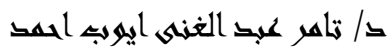

وبدرجة كافية لتحقيق مثل هذه الغايات، لذلك لابد أن تعمل التتمية الاقتصادية على

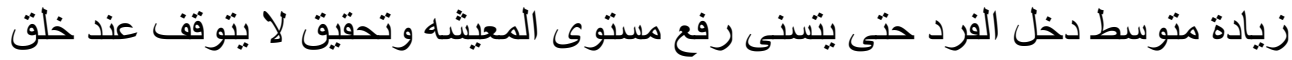
زيادة في الاخل القومى فحسب بل يجب أن نرتبط هذه رفئ الزيادة بتغيرات في في هيكل

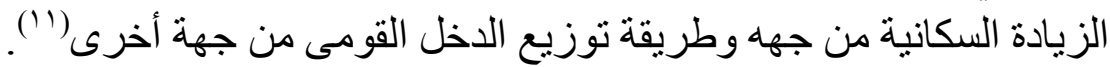
rـ تقليل التقاوت في الاخول في الثروات:

هذا الهذف للتنمية الاقتصادية هو في الو اقع هدف اجتماعي إذ أنه في معظم

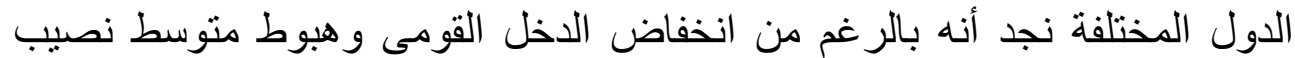

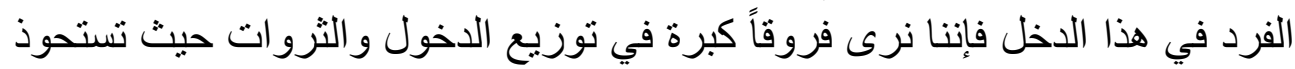

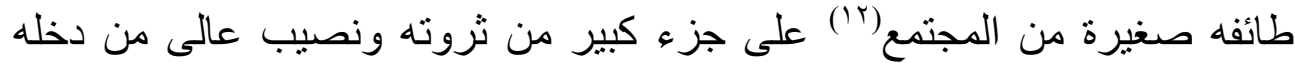

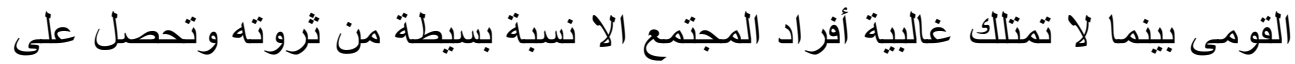
نصيب متو اضع من دخله القومى (r'). ع ـ تعديل التركيب النسبى للاقتصاد القومى:

يقصد بذلك عدم قدرة البلاد على الاعتماد على قطاع واحد من الانشطة

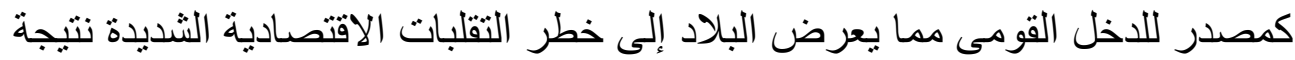

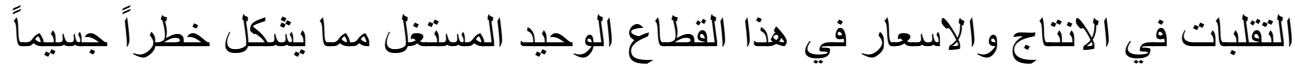
على هدوء واستقرار مجرى الحياة الاقتصادية لذلك يجب على التى القائمين بأمر التنمية في البلاد إحداث توازن في القطاعات و عدم الاعتماد على قطاع واحد كمصدر للاخل فئل

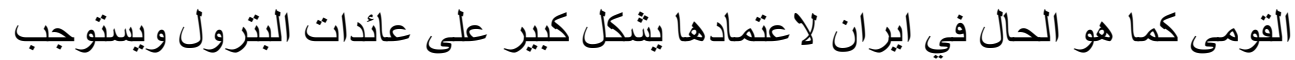

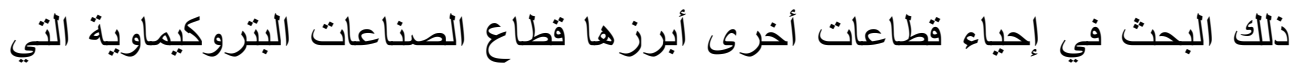

تمنل إحدى معالم التطور الاقتصادى من أجل الوصول إلى تنمية اقتصادية شاملة (ئل). هـ دفع مستوى حياة العمال:

ويتم ذللك عن طريق تلبية حاجياتهم الاساسية ويتضمن هذا الهدف

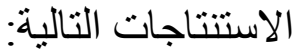

العدد الر ابع الجزء الثاني 9 ب ب

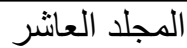




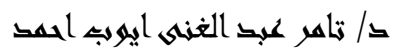

أـ ضرورة رفع انتاجية العمل دون أن يتم ذلك على حساب الاستخدام خاصة أن دولة منتل اير ان تثميز بمعدل تز ايد سكاني هام.

ب- ضرورة التحكم الواضح في ميدان تنظيم النشاط الاقتصادى وخصوصاً

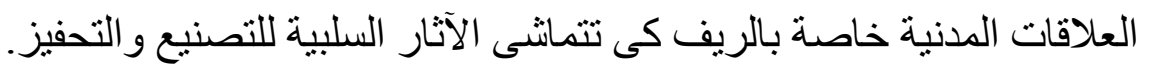

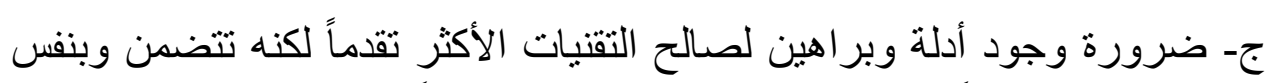
الوقت وعيا حاداً تجاه التبعيه التكنولوجية الولة ولين المعقدة جداً. دـ توجيه الاستثمار ات بطريقة تشجع مباشرة أو بصورة غير مباشر على انتاج

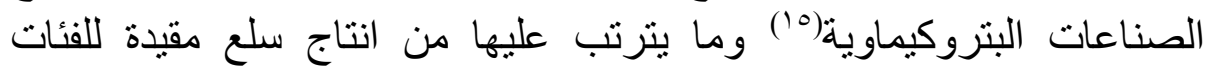
الثعبية.

\section{ثالثاً: مصادر تمويل التنمية الاقتصادية:}

من الطبيعى أن يكون تمويل التنمية الاقتصادية في البلدان المتخلفة ومنها

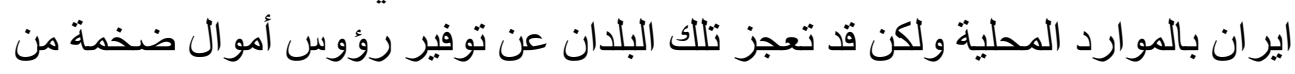

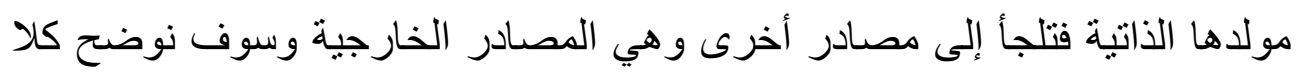

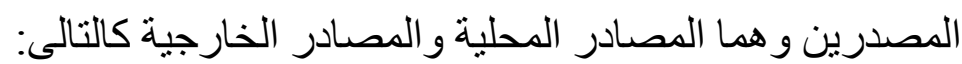

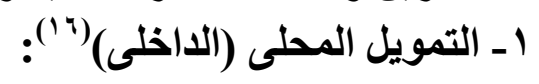

يعتبر التمويل المحلى (الداخلى) هو الأساس، ذللك أن الاعتماد في تمويل التنمية يجب أن يرتكز في الأساس على الموارد المحلية نذالئ الذكر منها.

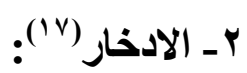

يعرف بأنه الامتناع عن الاستهلاك وكلما زاد الامتناع عن الاستهلاك تزداد

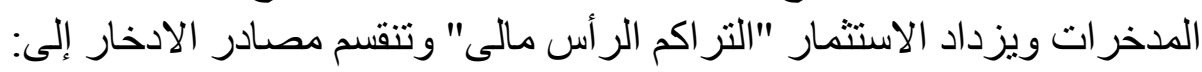

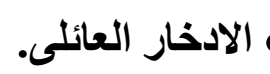

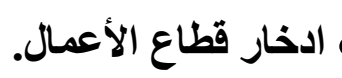




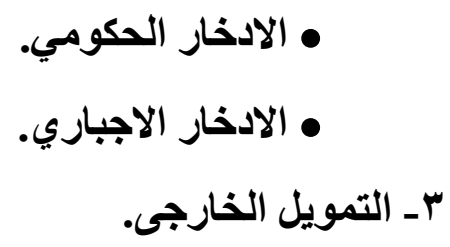

نظر اً لعجز المدخرات الوطنية (المحلية) في توفير رأس المالى الكافى لتمويل

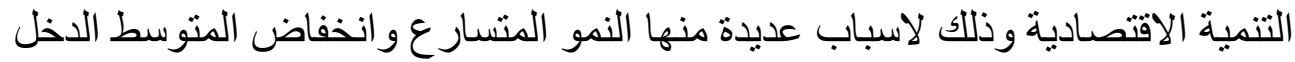

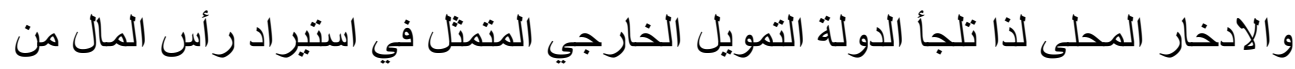

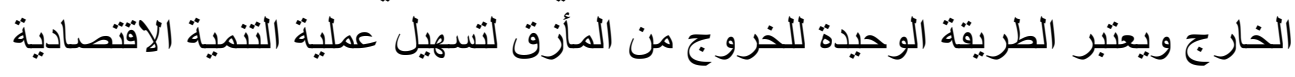

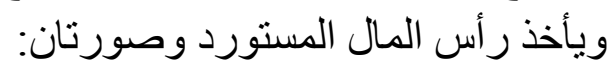

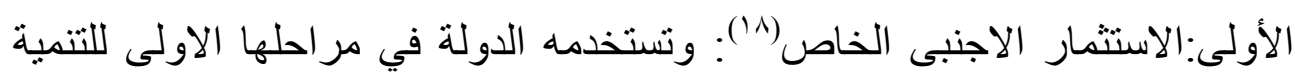

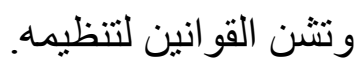

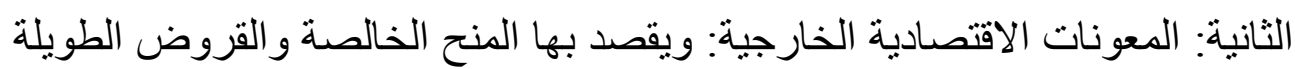

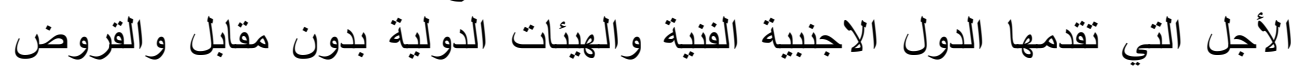
المختلفة

رابعاً: متطلبات التنمية الاقتصادية:

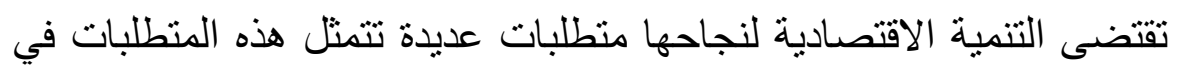
التغير ات المتعددة للمجالات السياسية والاجتماعية و الثقافية في المجتمع.

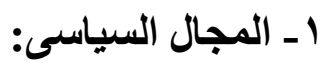

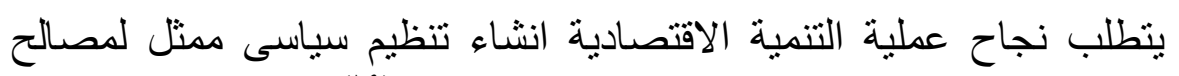

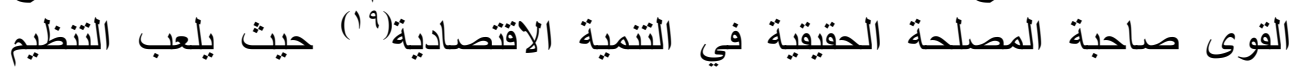

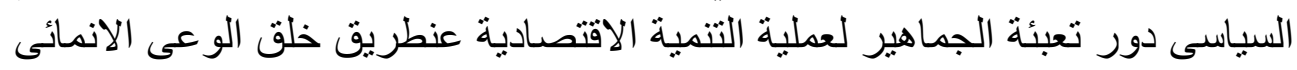

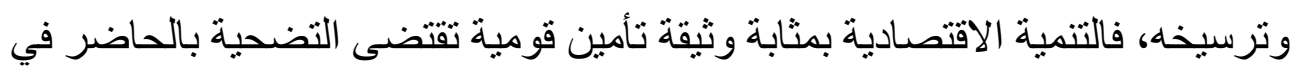
سبيل المستقبل وخلاصة القول أن التنمية الاقتصادية تتطلب خلق فئة حمية قوية وتلاحم 


\section{العوائي البتخرولية وأثرها علىى التنمية الاثتماكية}

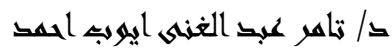

قومى من أجل انجاح عملية الانماء الاقتصادى والاجتماعي والتنظيم السياسى هو التها الهيئة التي يوكل إليها خلق هذه الحمية وخلق هذا التلاحم.

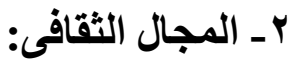

تتطلب التنمية الاقتصادية تغيرات جو هرية في نظام التعليم الفائد، تتمثل هذه

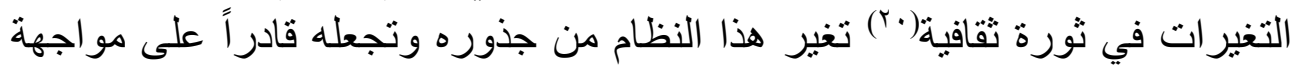

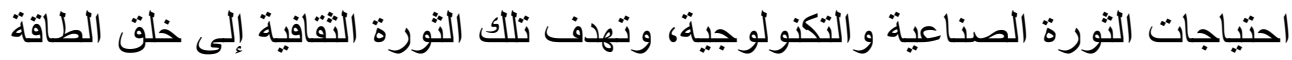

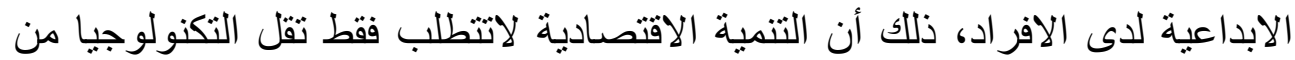

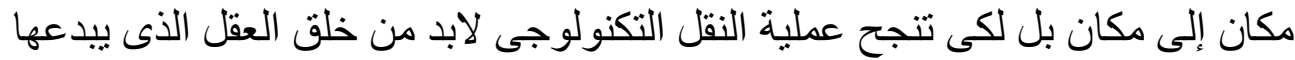
ويدير ها ويسير ها مع الاعتناء بها، واخيراً تتطلب عملية التنمية الاقتصادية تغييراً جوهرياً في مناهج التعليم السائدة لخلق العقلية العلمية.

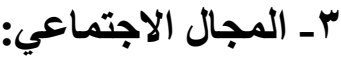

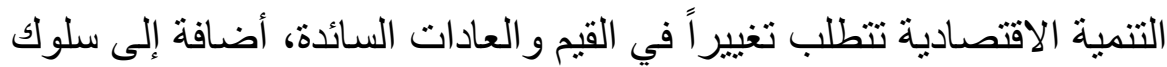
الأفراد ونظرتهم للنشاط الاقتصادى والعمل كقيمة اجتماعية، وهذا يقتضى التغية الغييراً

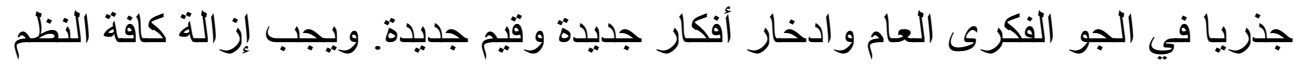
الاجتماعية مثل نظام الطوائف الذى يعوق عملية المرونة الرأسية أى قدرة الإنية الانسان

على الانتقال من مهنة إلى مهنة (ب). ع ـ المجال التظظيمى (الاداري):

تحتاج التنمية الاقتصادية إلى تغير جو هرى في بعض التنظيمات و المؤسسات الاقتصادية السائدة أو خلق مؤسسات وتتظيمات جديدة. و لا شك أن النية التنمية الاقتصادية

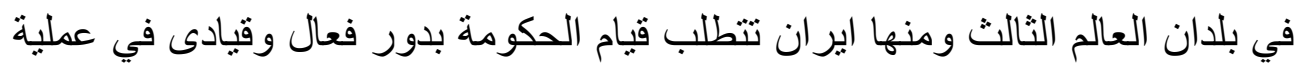
النمو الاقتصادى ويكون ذلك يتمتع الجهاز الحكومى على درجة عالية من الكفاءة

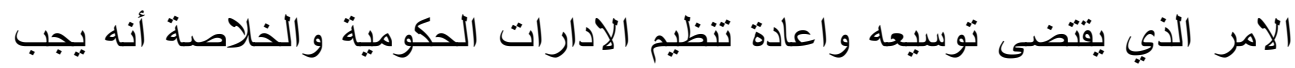




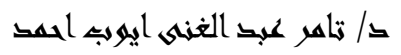

ازالة كافة القيود التنظيمية التي تقف عائقاً أمام الوصول إلى أقصى كفاءة ممكنه

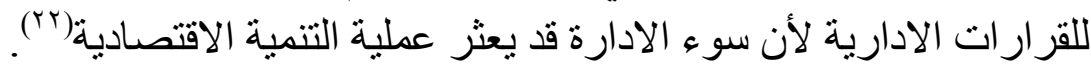
خامساً: استراتيجية وأساليب التتمية الإقتصادية: ا - استراتيجية التنمية الاقتصادية(rT)

إن تحديد الاستر اتيجية العامة للتنمية الاقتصادية يختلف من بلد لآخر وتحديد

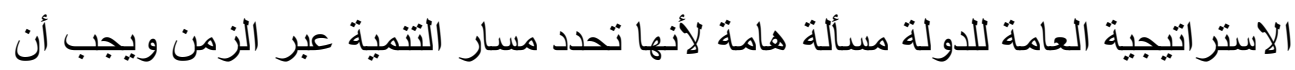
تتصف تلك الاستراتيجية بالثمولية (تغطى كافة قطاعات الاقتصاد القومى)

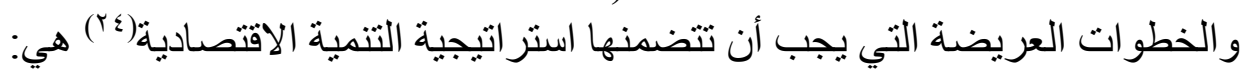

$$
\text { ـ تحديد المشروع الاجتماعي. }
$$

ـ تشجيع التكامل و الاندماج الاقتصادى بين القطاعين والخاص. ـ خلق سياسة مالية نقدية تجارية عامة ملائمة لتشجيع الاستثمار العام و الخاص. ـ العدالة الاجتماعية (تكوين رأس المال و الادخار و الحد الأدنى من التضخم). r اسليب التتمية الاقتصادية(ro)

هنالك عدة أساليب للنهوض بالتنمية الاقتصادية أهمها: ـ توفير رأس المال(جr) الملائم و اللازم للتنمية مادياً وبشرياً. ـ توفير انظمة التعليم المعتمدة في إعداد قوة العمل. ـ تطوير آليات تخطيط قوة العمل. ـ تطوير آلبات الاختيار والنقيين والتحتية البشرية(rV). ـ خلق نظام الحو افز و المكافأت التشجيعية. ـ توفير المناخ الاقتصادى والاداري المناسب. 


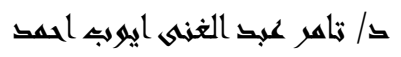

$$
\text { ـ اعداد وتأهيل البد العاملة بمختلف التخصصات و المهار ات و الكفاءات. }
$$

ـ تزويد القوى العاملة بالمعارف و الخبر ات و المهار ات اللازمة بهدف تحقيق التنمية

الاقتصادية.

$$
\text { ـ تبسيط الاجر اءات و الحد من الروتين. }
$$

ـ تخصيص أيام در اسية في البحث العلمى('^^).

ـ توفير البيئة المناسبة وكذا المناخ المناسب الذي يساهم في حل مشاكل التنمية

الاقتصادية.

مما لاشك فيه أن هذه الحلول والاساليب تعتبر جميعها روافد في تخفيف

$$
\text { سادساً: معوقات التنمية الاقتصادية وتؤدي إلى زيادة في الاخل القومى. }
$$

هناك مجموعة من المعوقات التي تواجه التنمية الاقتصادية منها ما هو

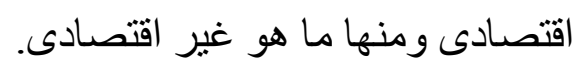

1 المعوقات الاقتصادية:

من أهم المعوقات الاقتصادة ما يلي:

أ. القوى العاملة.

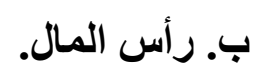

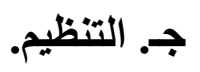

د. الموارد الطبيعية:

هـ. التجارة الخارجية.

العدد الرابع الجزء الثاني 9 بـ

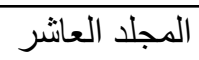




\section{العوائي البتخرولية وأثرها علىى التنمية الاثتماكية}

ق/ تاهر عمب الغنهى ايهوبه المقد

\section{r ا بـ المعوقات غير الاقتصادية:}

تتنوع تللك المعوقات من اجتماعية ثقافية ومعوقات سياسية:

- بالنسبة للأولى فإنه يوجد هناك عادات وتقاليد اجتماعيةتقف أمام عملية التنمية

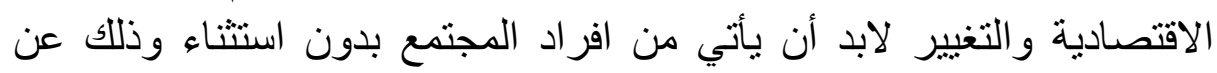

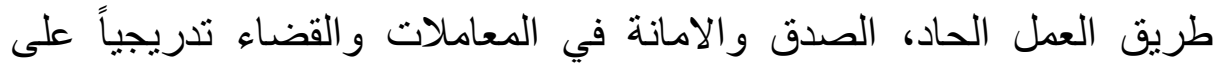

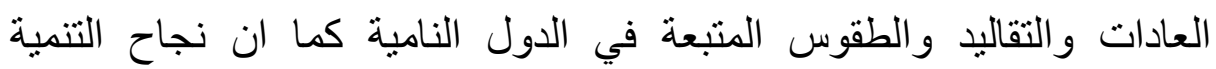
الاقتصادية يتطلب معه العمل على انتشار التعليم وتخفيض نسبة الأمية لأن الشخص غير المتعلم لا يدرك احيتاجات التنمية الاقتصادية(99). - بالنسبة للثانية فإن العامل السياحى يعتبر من أهم المعوقات لأن عدم توفر

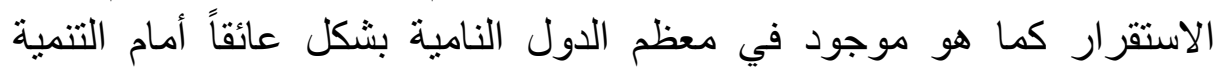
ويتطلب اتخاذ القرار ات الاقتصادية التتموية الاستقر ار السياسى للدوله. الفصل الثانى

الإستثمار الأجنبى فى مجال الصناعات النفية وأثره على تعظيم العوائد

تتص غاليبية الدول النامية ـ إن لم يكن كلها لجذب الإستثمار الأجنبي المباثر إنـا

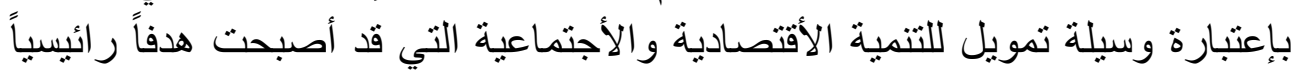

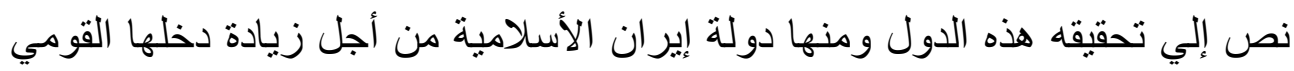

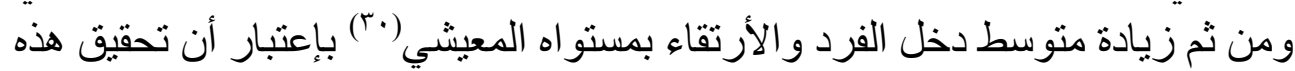
الأهداف و الغايات الثقيلة يتطلب توفير موارد مالية تفوق في الطلب ما يمكن تعبئتة من

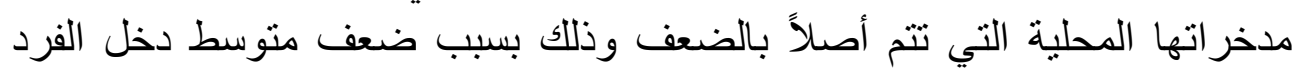
حديثا. 


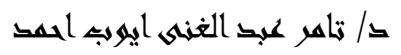

وتسرب لبعضها في أغراض غير أقتصادية حيثا أخر وهربها إلي الخارج

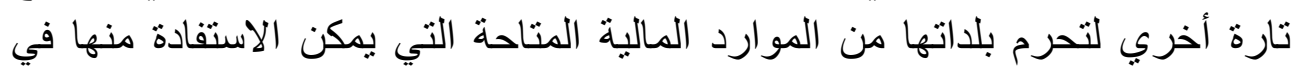

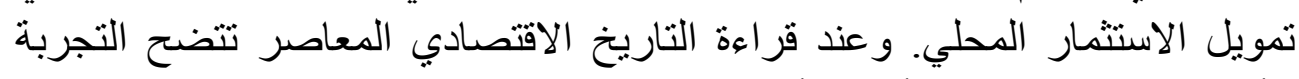

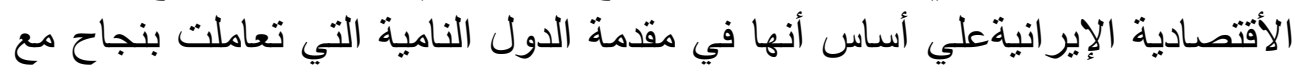

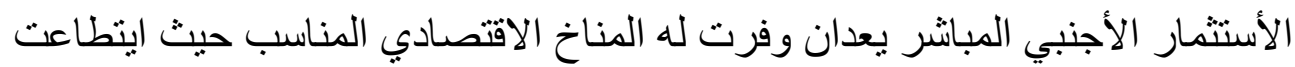

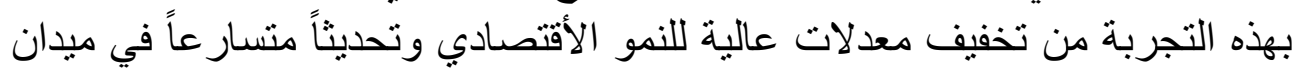

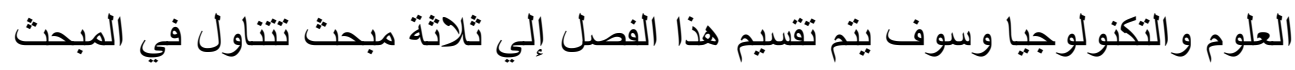

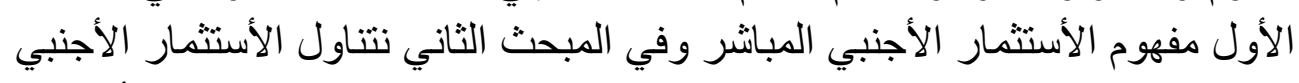

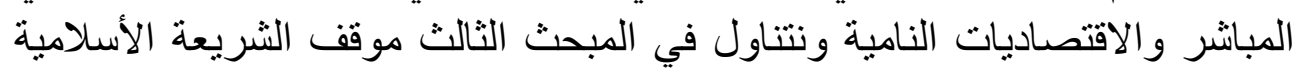
من الأستثمار الأجنبي المباثر. مفهوم الأستثمار الأجنبي المباشر:

يمثل الأستثمار النشاط الأقتصادي الأساسي؛ ومفتاح التنمية الأقتصادية لدول

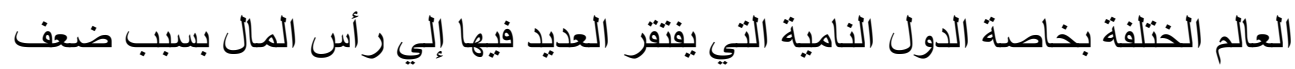

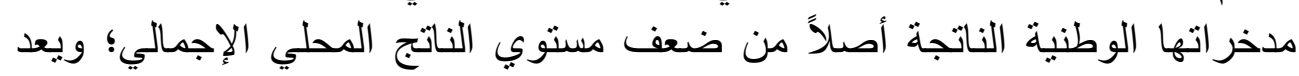

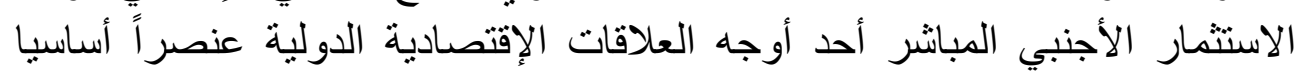

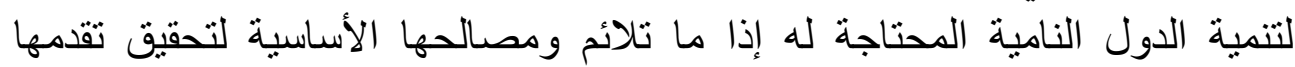

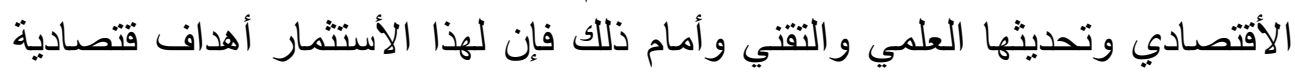

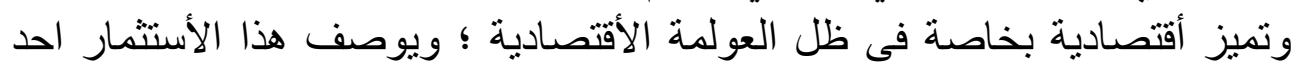

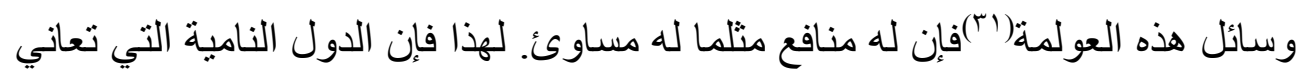

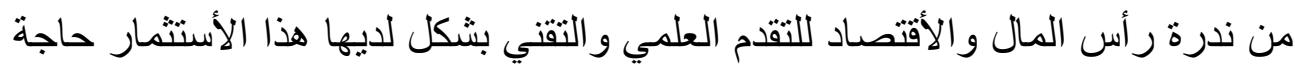

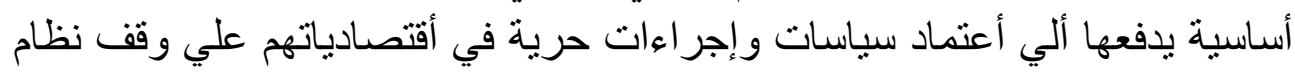

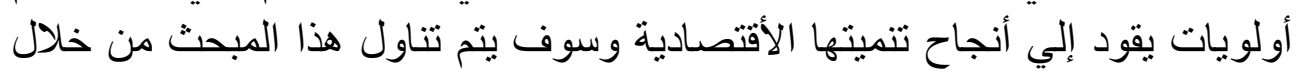

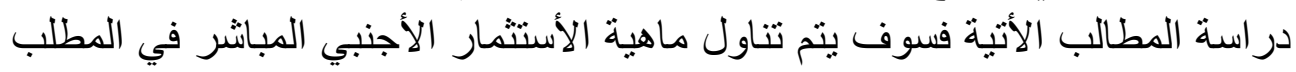




\section{العوائي البتخرولية وأثرها علىى التنمية الاثتماكية}

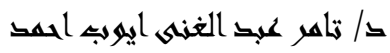

الأول وتناول في المطلب الثاني أنواع ومحددات التوزيع القطاعي للأستثمار المباشر وسوف يتم تناول الأستثمار الأجنبيفي الصناعات البتروكيماوية في المطلب الثالث.

ماهية الأستثمار الأجنبي المباشر:

وصور تاريخ الأستثار الأجنبي المباثر في الدول النامية إلي القرن التاسع

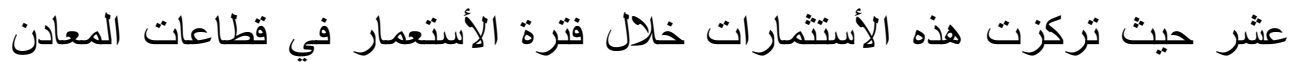

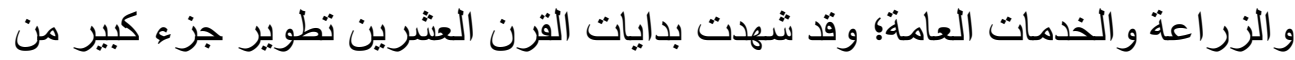

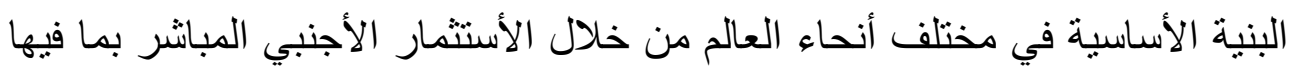
الطاقة الكهربائية و الأتصالات السلكية و اللاسلكية(r').

وتعد تغير نمط الأستثمار الأجنبي المباثر في اعقاب الحرب العالمية الثانية

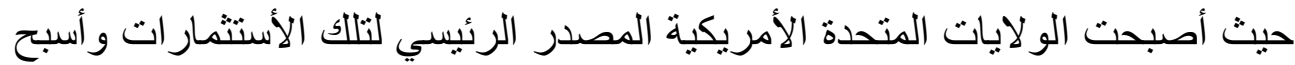

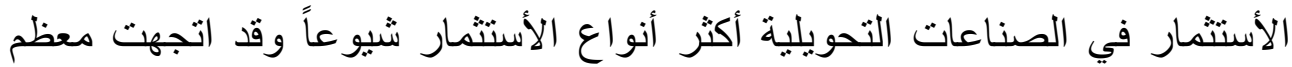
الدول النامية ومنها إيران خلال الخمسينيات و الستينيات استر اتيجيات تنموية مستنده

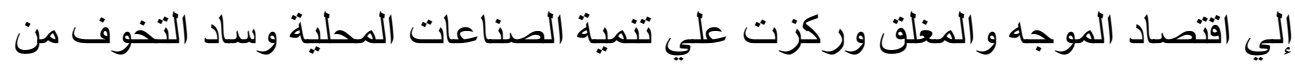

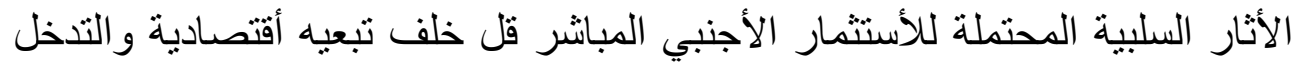

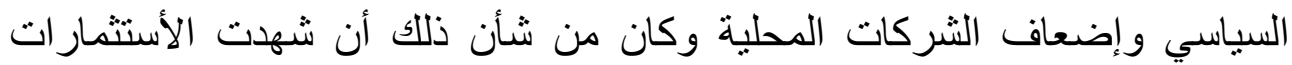
الأجنبية المباشرة تر اجعا ملحوظا في تكل الحقبة افتقرت أنذالك في شكل هدايا ومنح وقروض ولتحديد ماهية الأستثمار الأجنبي المباشر فإنه سوف يتم تناوله من خلال الأتي:

أولاً: التعريف اللغوي:

الاستثمار في اللغة مشتق من الثمر أي حمل الثجر وأنواع المال(بّ) ويقال

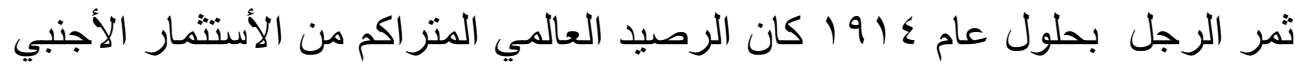

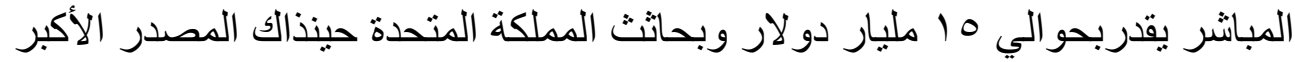

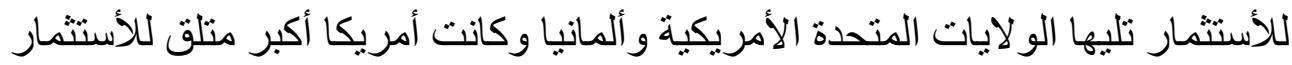

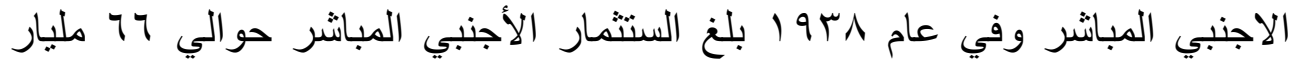




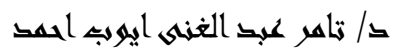

دو لار وكانت الثركات البريطانية لا تز ال أكبر المستثمرين وقد توجه أثر من نصف

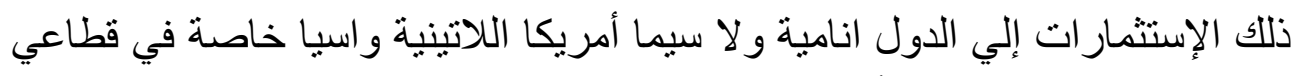
الزر اعة و التعدين و البنية الأساسية.

\section{ثانياً: التعريف الفقهي:}

يتعذر الوقوف علي تحجيج صريح لمفهوم الاستثمار من المنظور الفقهي

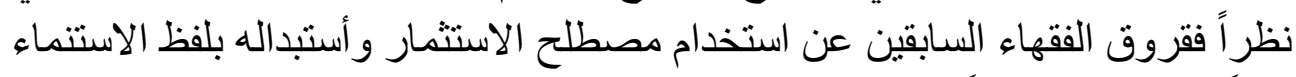

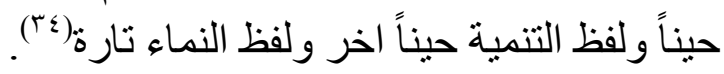

فقد ذر الكاساني في كتابة بدائع النائع عن تعريفه لعقد المضساربة أن المقصود

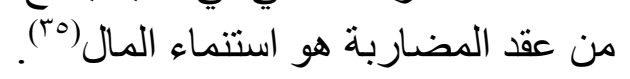

كما ذكر الفقيه المالكي الأمام الدردير في كتابه الشرح الالصغير لقظ التنمية

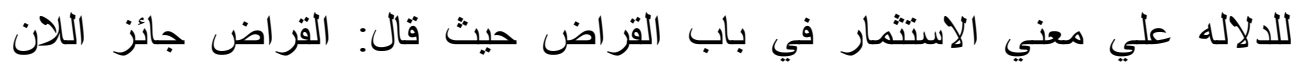

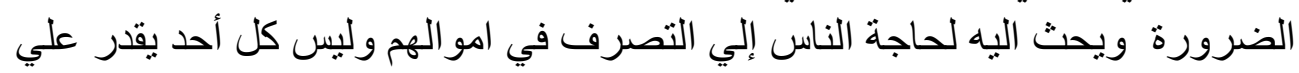
التنمية بنفسه.

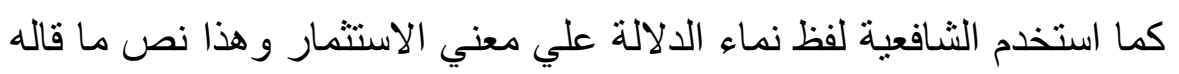

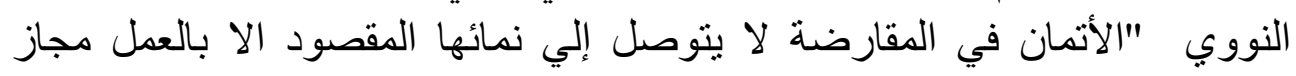

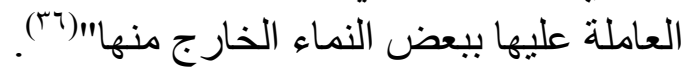
بينما قال الثير ازي(ه`) "التجارة لطلب لا نماء المال".

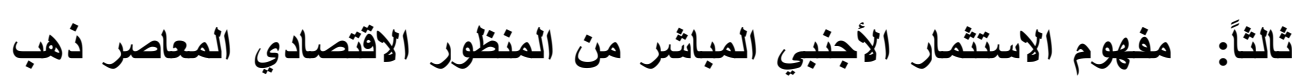

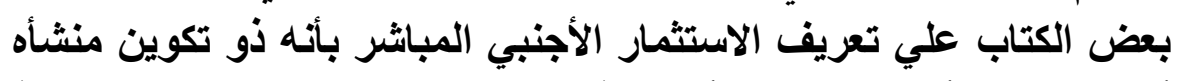

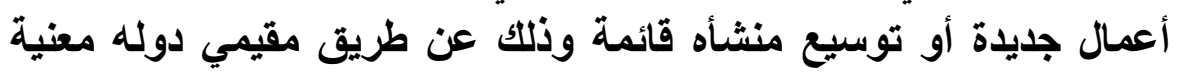

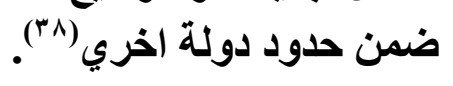

ويعرفه البعض بأنه "نشاط استثماري طويل الأجل يقوم به مستثمر غير مقيم

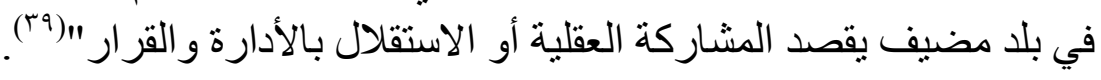

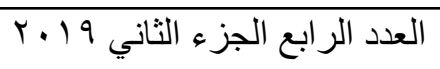

المجلد العانشر 


\section{العوائي البتخرولية وأثرها علىى التنمية الاثتماكية}

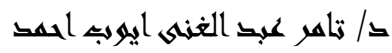

كما يعرفه البعض الكتاب بأنه "الحصة النانية للمستثمر المقيم في اقتصاد ما

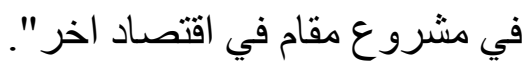

كما يفسره البعض بأنه "نشاط اقتصادي مصدره الأساسي المدخر ات الوطنية

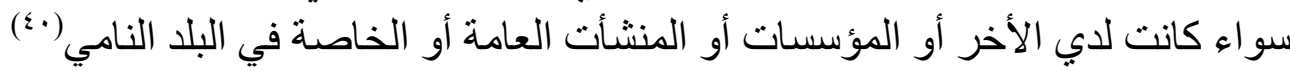

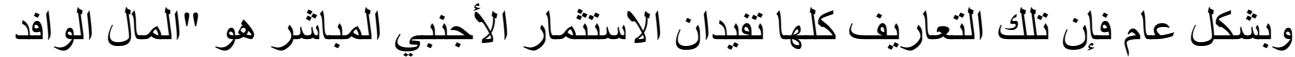

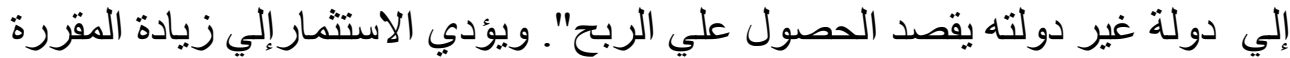

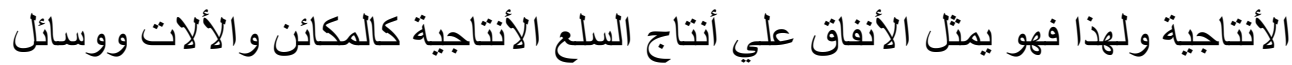

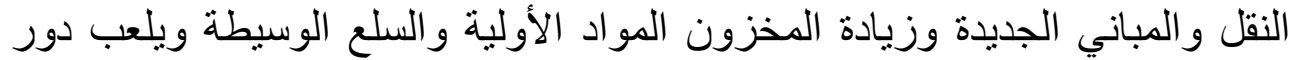
رئيسي وأساس في التنمية الأقتصادية'(1).

وتكمن أهميته من خلال مجمو عة من المسائل أهمها الأتي:

ا. زيادة الأنتاجية والأنتاج مما يؤدي إلي زيادة الدخل القومي ومن ثم زيادة

متوسط دخل الفرد وبالتالي تحسين مستوي معيشة السكان (rادئ. Y. توفير فرص العمل وتخفيض نسبة البطالة.

r. حصول البلد علي العملات الأجنبية الصعبة من خلال ماينتج من سلع للتصدير وبالتالي تأثثيره الأجابي علي ميز ان المدفولت الاني ع. ز زيادة معدلات التكوين الر أس مالي للبلد ("זء). أنواع ومحددات والتوزيع القطاعي للاستثمار المباشر: لا يوجد في الواقع تحديد دقيق لكافة أنواع الاستثمار الأجنبي المباثر مما

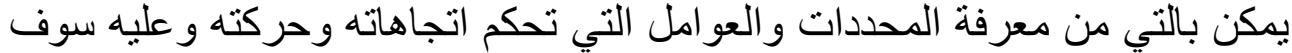

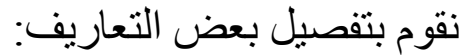




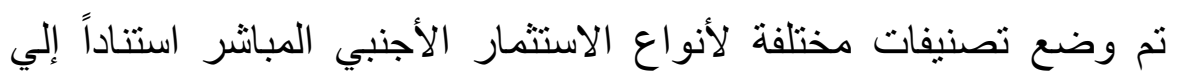

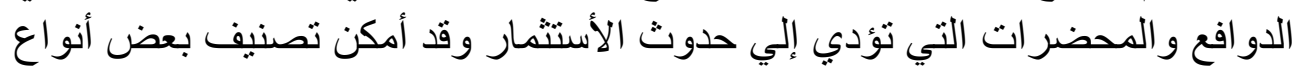
الاستثمار الأجنبي المباشر وفق المحددات التالية:

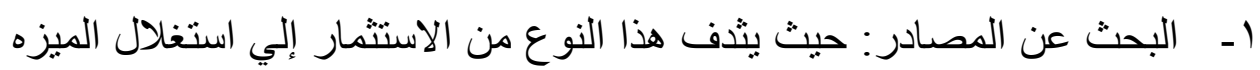

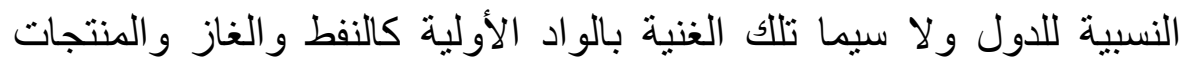
الزر اعية فضلاً عن الاستفادة من انخفاض تلكفة العمالة أو وجود عمالة ماهرة

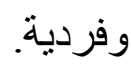

r- البحث عن الأسواق: يهذف هذها النوع من الاستثمارات عادة إلي تلبية

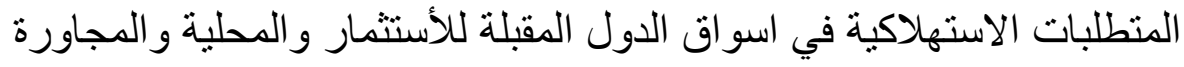

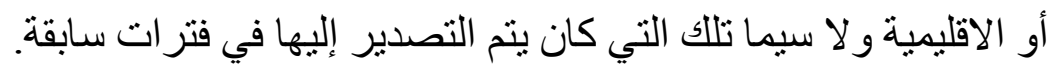

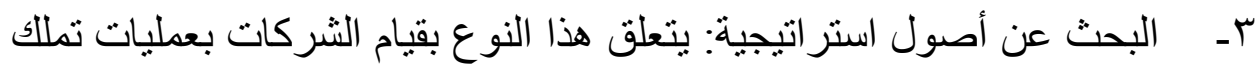
أو شر اكة لخدمة أهدافها الاستر اتيجية:

ثنانياً: محددات الاستثمار المباشر:

هنالك ثلاثة عوامل رئيسية تعتمدها الثركات المتعددة الجنسية والعابرة

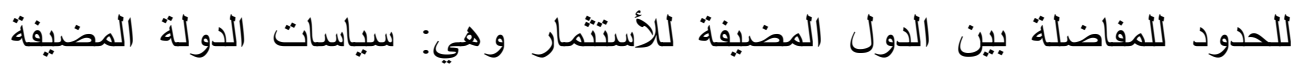

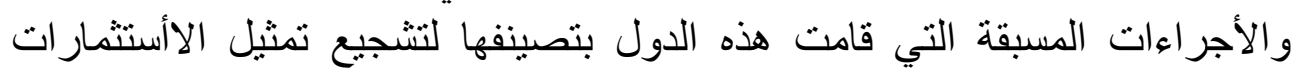

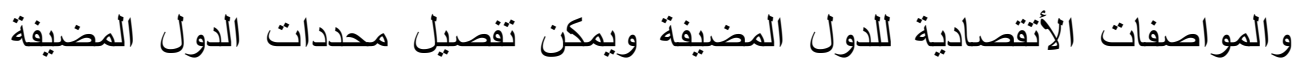
للأستمثار ضمن ثلاثة عناوين رئيسية هي: للأنية

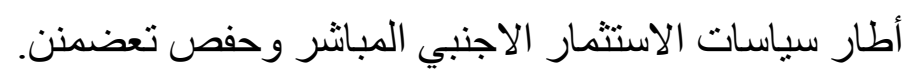
• الاستقرار الأقتصادي و السياسي و الأجنماعي.

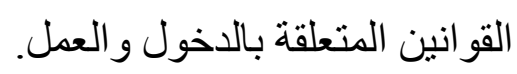




$$
\text { معايير معاملة فروع الثركات الاجنبية. }
$$

سياسات العمل و هيكلة الأسو اق لاسيما المناقسة وسياسات الدمج و الأئتمان.

$$
\text { • الأتفاقيات الدولية حول الأستثمار الأجنبي المباشر. }
$$$$
\text { سياسات وبر امج الحفحضة. }
$$

السياسات التجارية (التعريقة الجمركية سياسة الحماية الوطنية).

$$
\text { السياسات الضريبية. }
$$

تر ابط الاستثمار الأجنبي المباشر و السياسات الاقصادية.

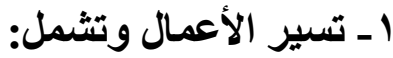

هـم وتعزيز الاستثمار ويتضمن بحيث المناخ الاستثماري وسمعة الدولة وتوفير

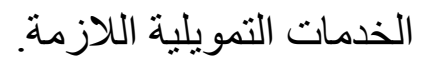

$$
\text { الحوافز الاستثمارية. }
$$

التكلفة المنخفضة فيما يتعلق بفساد وسوء الدارة.

الر احة الأجتماعية لتوفير المدارس ثنائية اللغة وتو عية الحياة وغير ها.

$$
\text { خدمات ما بعد الأستثمار. }
$$

\section{ץ- محددات الأستثمار الأجنبي المباثر في الدول المضيفة:}

وهي تختلف دولة لأخري وذللك وفقا لسياسات تللك الدول ورغمها في فتح

اسواقها للأستثمار الأجنبي المباشر ومدي ملائمة البيئة الأقتصادية لقيام تلكي

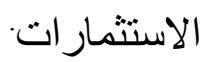


ثالثاً: التوزيع القطاعي للأستثمار الأجنبي المباشر:

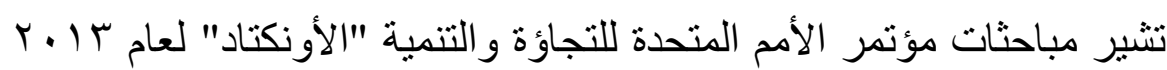

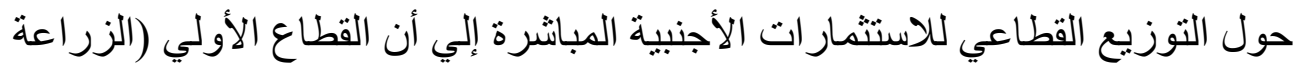

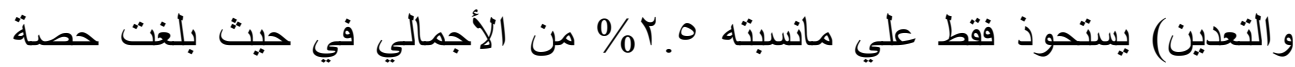

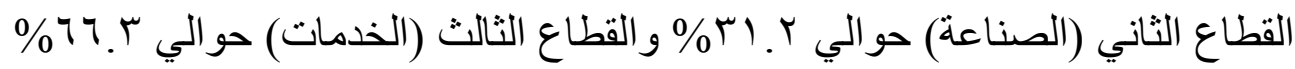
أو ضمن القطاع الثاني كانت قطاعات مثل النشر واعن والطباعة واعل والإنتاج الإعلامي

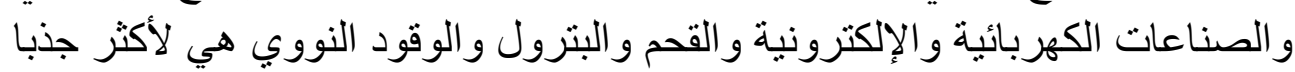
للأستثمار الأجنبي المباشر وبالمثل في القاع الثالث وفقد استكثرت قطاعات الاتهن النقل و التخزين والأتصالات والخدمات المالية بالحصة الأكبر من الاستثمار الأجنبي المباثر (๕๕).

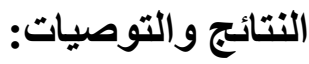

\section{اولا : النتائج}

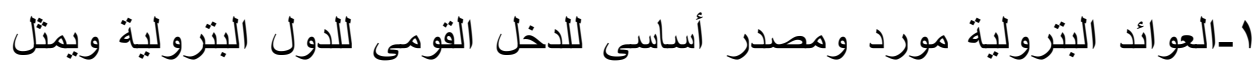

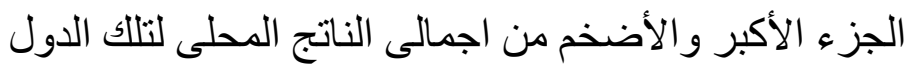
r العوائد البترولية متغيرة طبقا لعوامل عديدة منها السياسي والجيوغرافى الهى

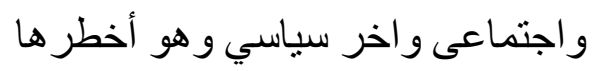

ب-حدوث انخفاض أو هبوط فى تلك العوائد يؤثر بشل ملحوظ على الوضع الاقتصادى لتلك البلدان

ع ـالصر اعات و التنافسات بين بلدان النفط تؤثر بشكل ملحوظ على أسعار النفط وبالتالى على حجم تلك العوائد البترولية

هـعدم وجود رؤية اقتصادية نفطية لمعظم بلدان البترول لها ناثير واضح وخطير على حجم تللك العو ائد

العدد الر ابع الجزء الثاني 9 ب ب المجلد العانشر 


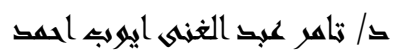

ثانيا : التوصيات

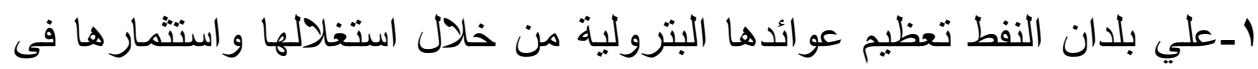
مشرو عات كبرى تعود بالنفع على دولها علئ

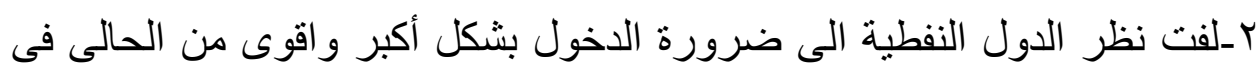

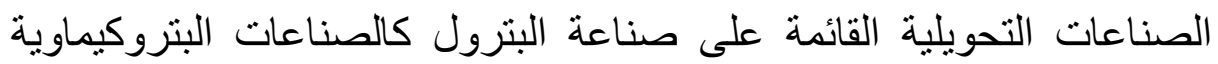

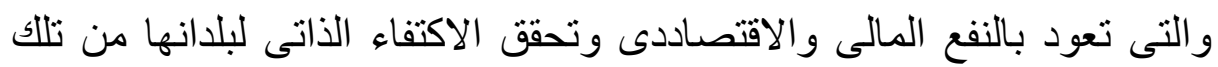

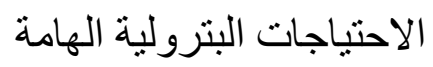

r-ضرورة حفاظ بلدان النفط فيما بينهم من علاقات خارجية و اقتصادية وسياسية

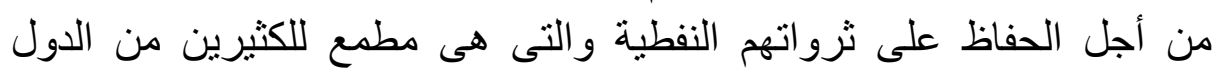
الر اسمالية اجن

ع الحفاظ على مستوى عادل لاسعار البترول يحقق النفع لكلا من الدول المنتجة

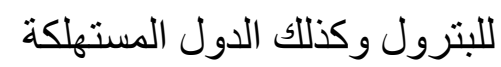

هـضرورة سعى بلدان النفط لوضع خطط استر اتيجية قوية لمو اجهة أزمات تقلبات وتذبذبات الاسعار والتى قد ينتج عنها هبوطا فى تلك الاسعار وذللك يؤدي بدورة فوره لأنخفاض حجم العوائد المتوقعة لتلك البلدان 
(') نظراً لأهمية التمية و السعى الحثيث لتحقيقها في واقع المجتمعات الانسانية، و لاسيما المتخلفة

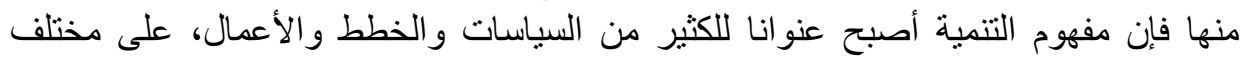
الاصعدة، كما أصبح هذا المصطلح مثقلاً بالكثير من المعانى و التعميمات، وأن كان بقتصر في ولان غالب الأحيان على الجانب الاقتصادى، ويرتبط إلى حد بعيد بالعمل على زيادة الانتاج الذى لإنى يؤدي بدوره إلى زيادة الاستهلاك لدرجة أصبحت معها حضار ات الأمم تقاس بمستوى دخل

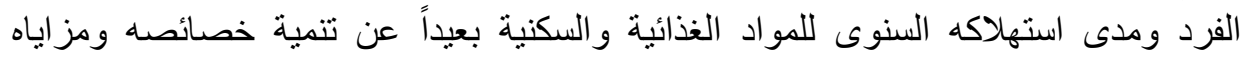
و اسهاماته الانسانية و إعداده لاداء الدور المنوط بـه في الحياة وتحقيق الأداف التي خلق من أجلها

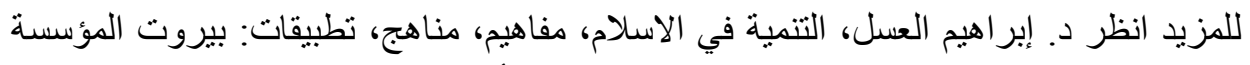

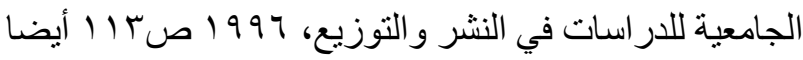

Schumpeter, J. \& Backhaus, U, 2003, The theory of economic development. PP. 61-16.

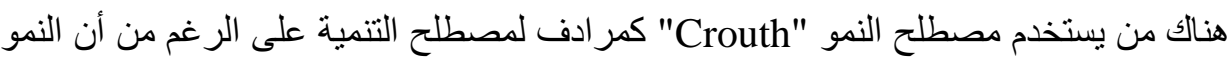

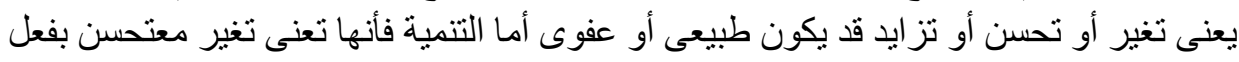

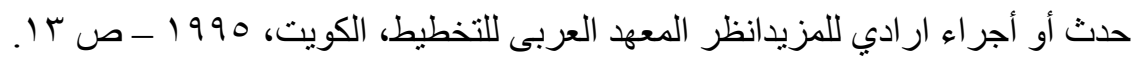

لم بستعمل هذا المفهوم في عصر العالم الاقتصادى آدم سميث و انما برز هذا المفهوم بداية في (v)

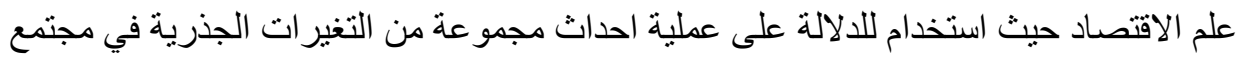

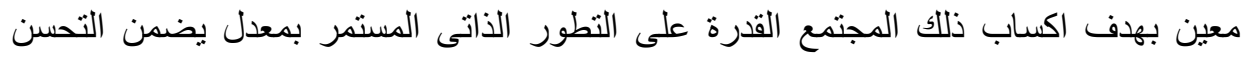

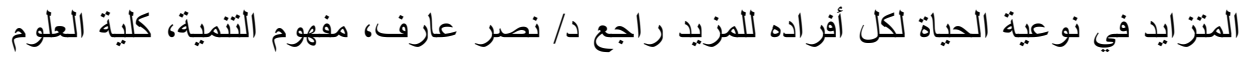

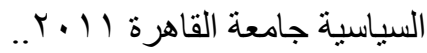

من بينها رأس المال البشرى والبنية التحتبة الاساسية والتنافس الاقليمى والاستدامة البيئية

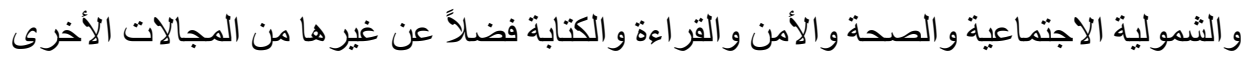
للمزيد انظر

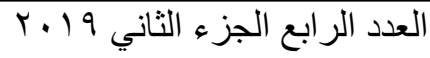




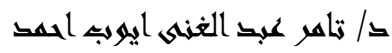

R. Conteras, "How the concept of development got started" University of low a center for international finance and development E-book.

(5) Sen, A (1983): Development: which way Now? Economic Journal, Vol. 93. Issue 372, PP -745-762.

(6) Ayres, Robert U. (1998): Turning point: an end to the growth paradigm, London earthscan publications, PP. 4-193.

من أكثر المؤشر ات استخداما لقياس مستوى التتمية الاقتصادية التي حققت في دولة ما بالمقارنة

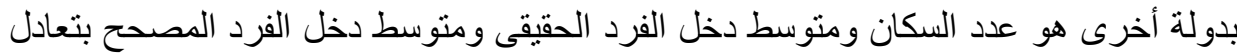

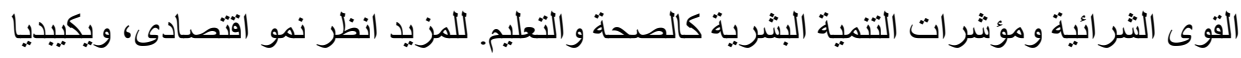

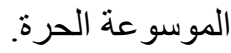

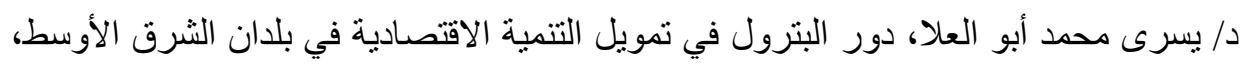

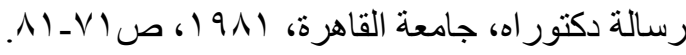

يبلغ عدد سكان ايران حاليا أكثر من • ^ مليون نسمة وتتألف ايران من اس محافظة للمزيد انظر

Encyclopedia Britannica, Article. Media ancient regian Iran.

(•) الدخل القومى المقصود زيادة هنا هو الدخل القومى الحقيقى لا النقدى،أى ذلك الذى بتمثل في

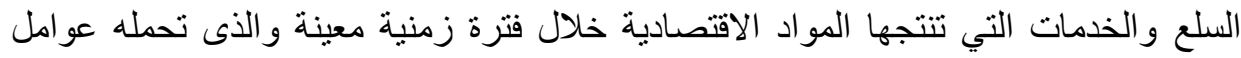

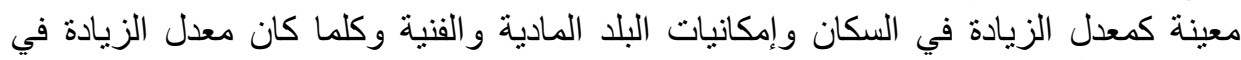

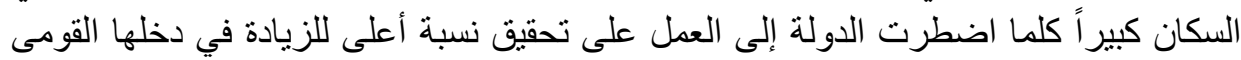

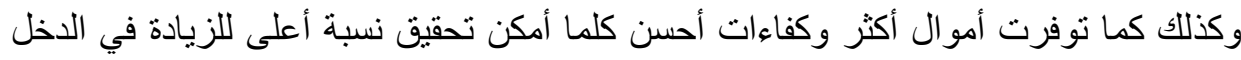

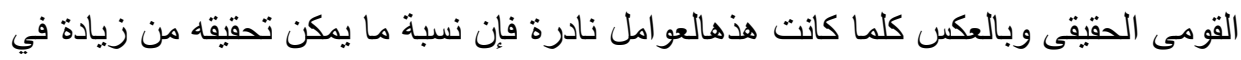

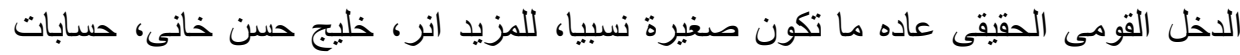

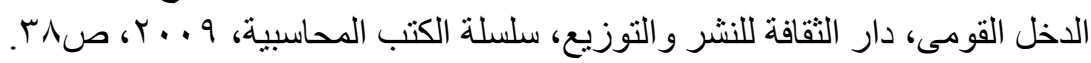

(') يجب العمل على وقف النمو المتزايد في عدد السكان نسبياً وذلك بالتحكم في معدل المواليد

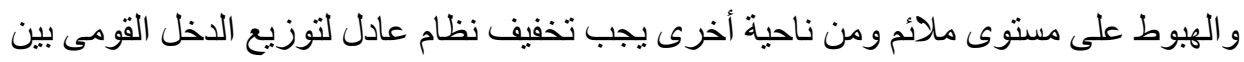

العدد الرابع الجزء الثاني 19 المجلد العاشر 


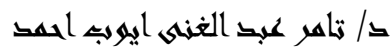

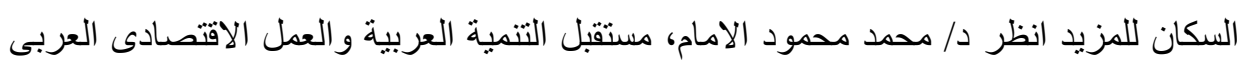

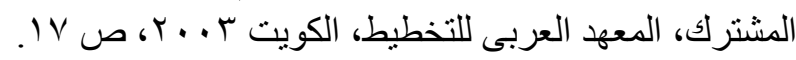

${ }^{(12)}$ David pearce, Edward Barbier, and Anil Markandya sustainable development and cost benefit analysis environmental economics center, London, 1997, P. 193.

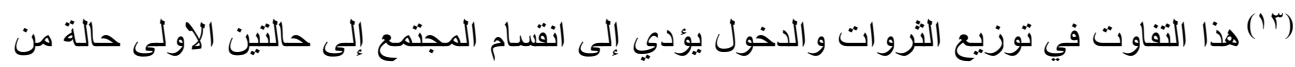

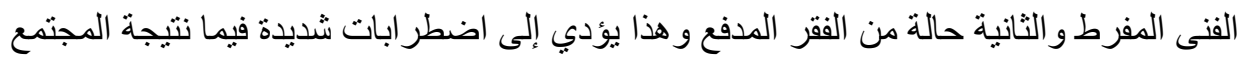

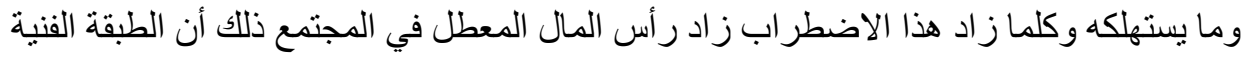

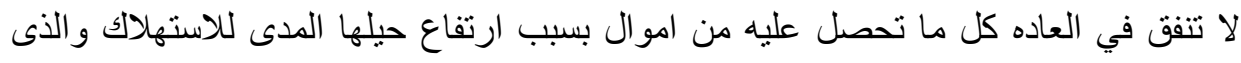

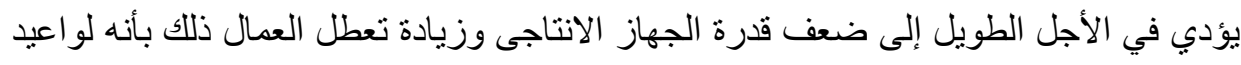

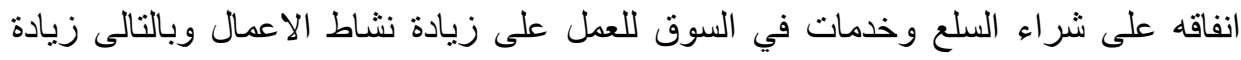

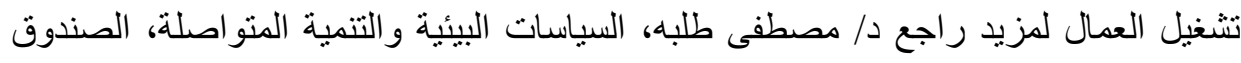

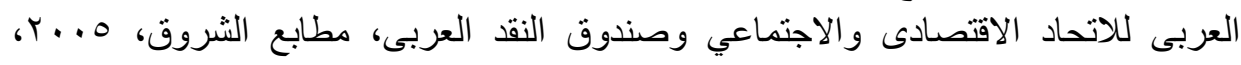

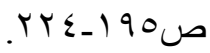

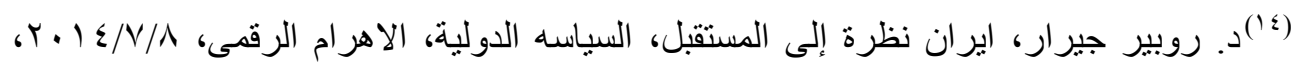
صזי. (10)قو اذ حمد القواذ، أهية الصناعة البتروكيماوية، جريدة الاقتصادية، النسخة الالكترونية، العدد

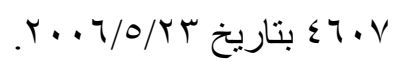

(1) يعتبر التمويل المحلى من الضروريات اللازمة و الاساسية لقيام التتمية الاقتصادية حيث تتطلب

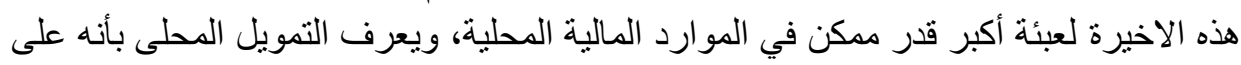

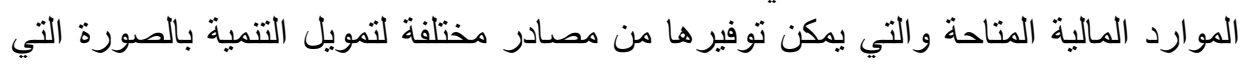

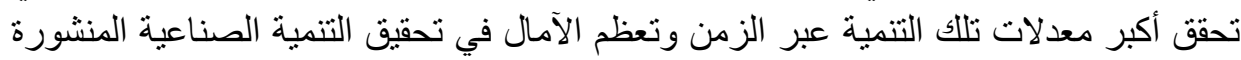

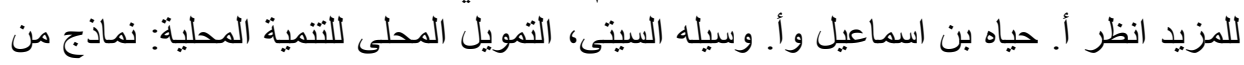
اقتصاديات الدول النامية، الملتقى الدولى حول: سياسات التمويل ولئه وأثرها على الاقتصاديات

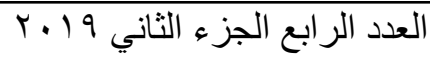
المجلد العاشر 


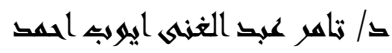

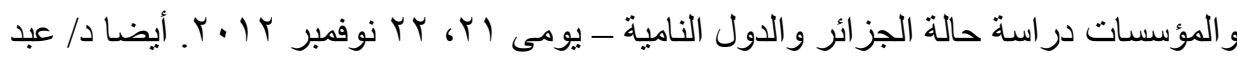

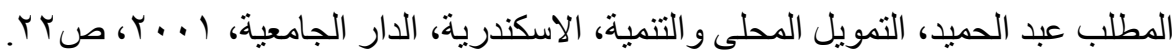

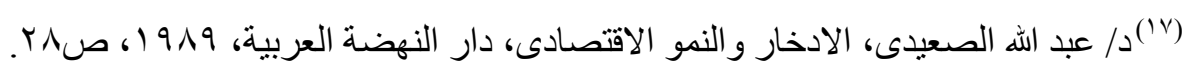

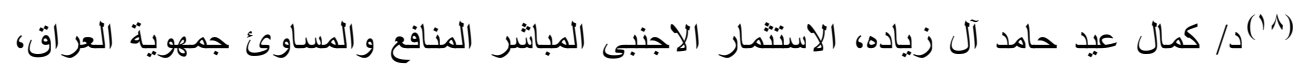

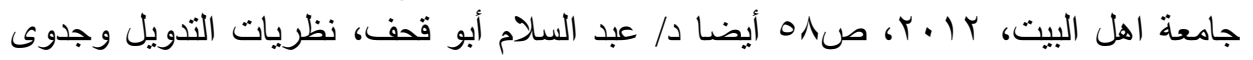

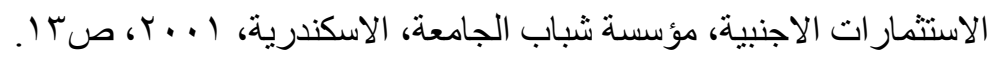

(19) بلاحظ أن التتمية الاقتصادية في الدول المتقدمة تحددها درجة الاستعداد الاقتصادى بصورة

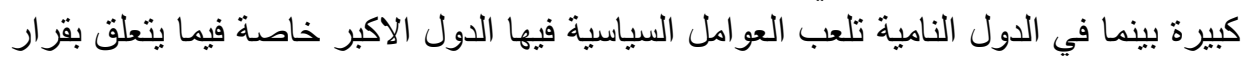

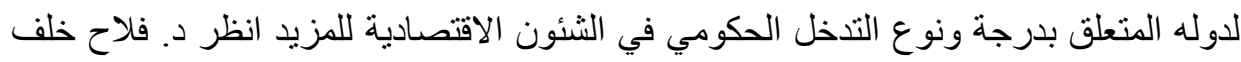

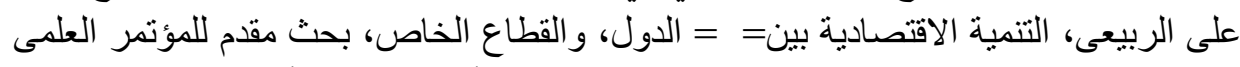

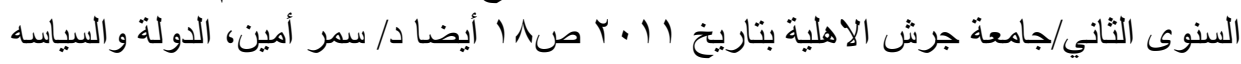

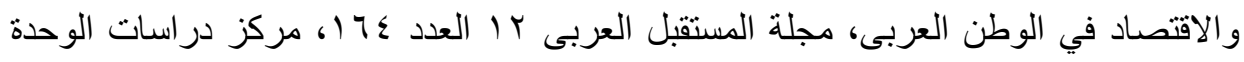

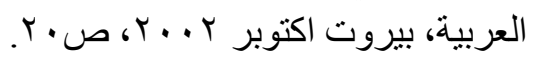

(r·(r) برزت الثقافة كضرورة تتموية - وبرز المدخل الثقافى في مكان الصداره من التتمية

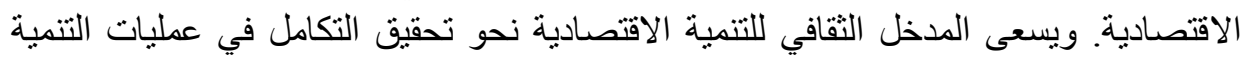

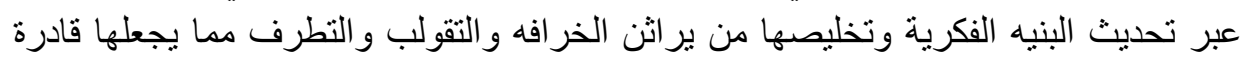

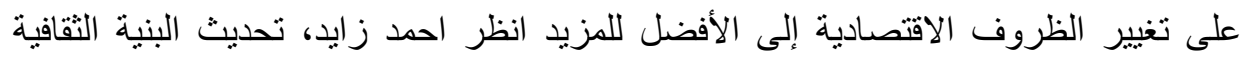

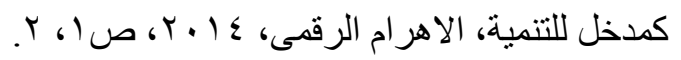

(rآيرتكز النظام الصناعى الحر على الفرد بدلاً من المجتمع فالحرية الفردية تعتبر هي الاساس

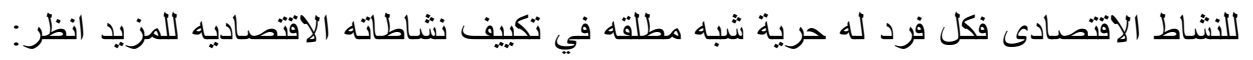

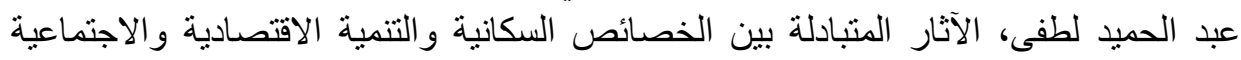

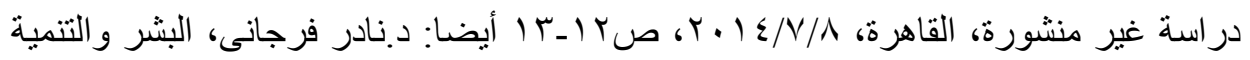

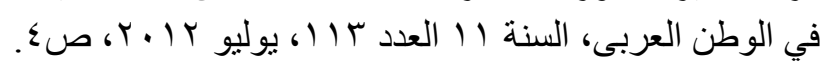

(r) بعتبر الاصلاح الاداري الحلقة الأساسية في الإصلاح الاقتصدى بشكل عام ولا يمكن انجاز

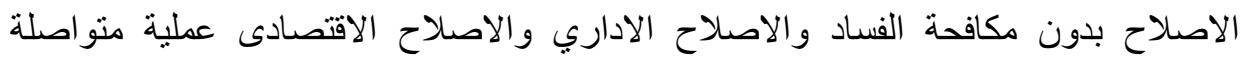

العدد الرابع الجزء الثاني 19 المجلد العاشر 


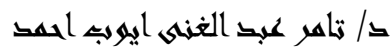

ومستمرة نجليها متغيرات الحياة وفي الدول النامية يجب مقاومة الفاسدين للمزيد أنظر جريدة

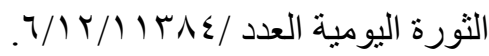

وند (Tr) محمد عبد العزيز عجيمه ود/ ايمان عطيه ناصف، التتمية الاقتصادية، دراسات نظرية

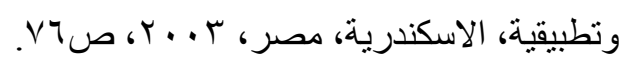

(r\&) (r) يوسف عبد الله صايغ، مقررات التنمية الافتصادية العربية، المؤسسة العربية للاراسات

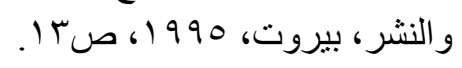

(ro) (10) رمزى ذكى، مشكلة الادخار مع دراسة خاصة عن البلاد النامية، دار القومية للطباعة

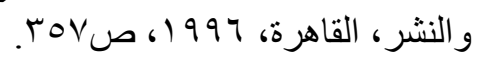

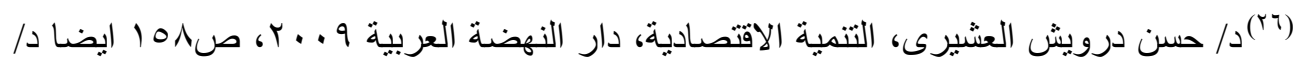

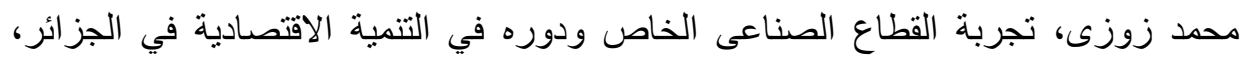

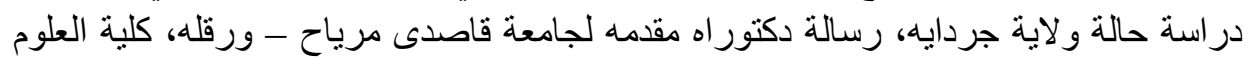

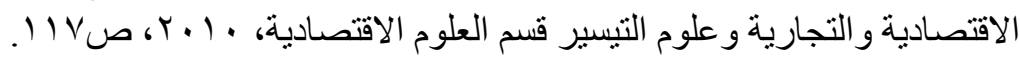

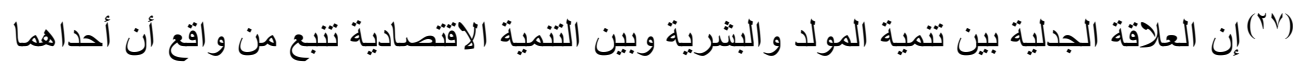

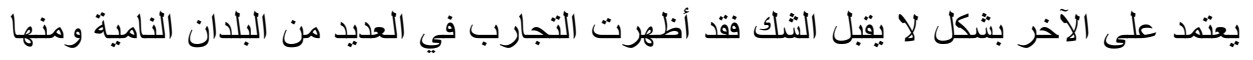

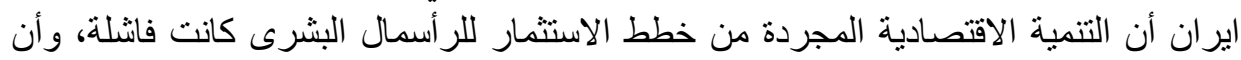

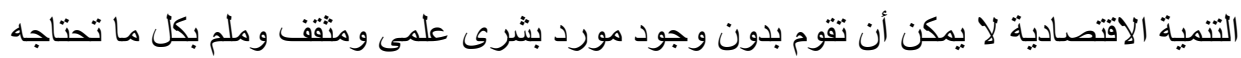

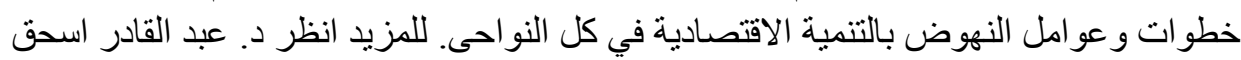

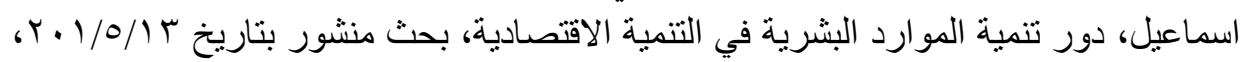

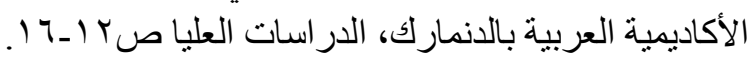

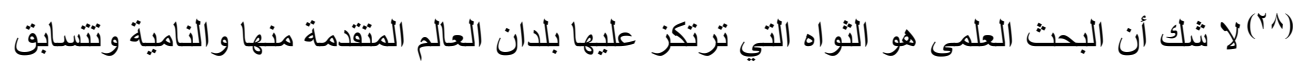

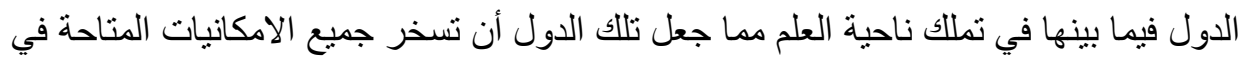

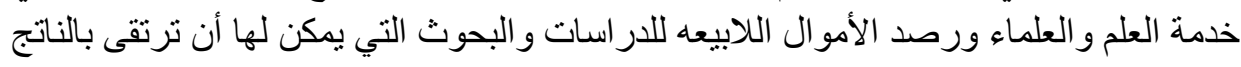

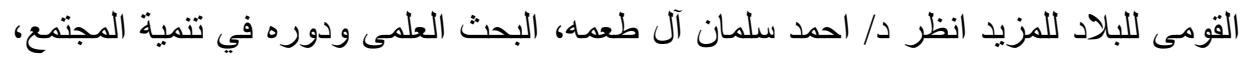

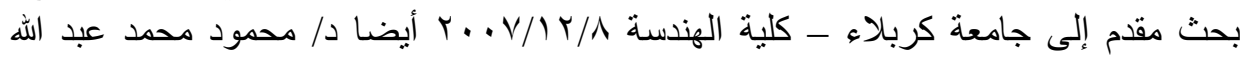

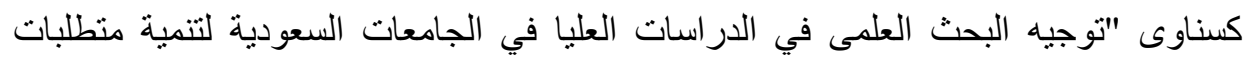

$$
\text { العدد الر ابع الجزء الثاني } 19
$$$$
\text { المجلد العاشر }
$$ 


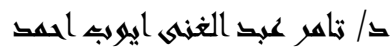

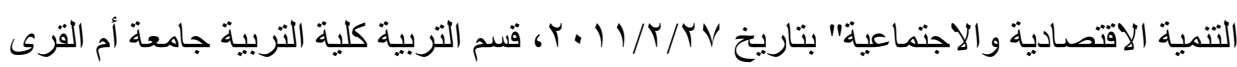

$$
\text { صمه و وما بعدها. }
$$

(r9) (r9/ سبد الحسينى، التنمية والتخلف، دراسة تاريخية بنائية طا، مصر، مطابع سجل العرب،

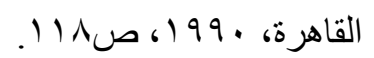

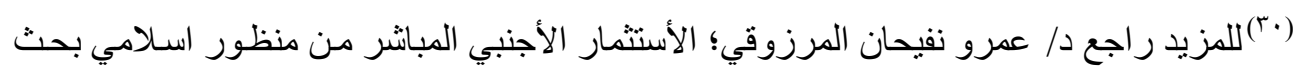

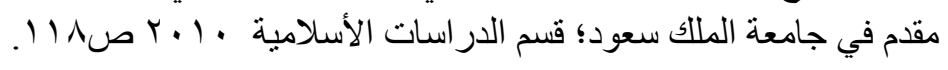

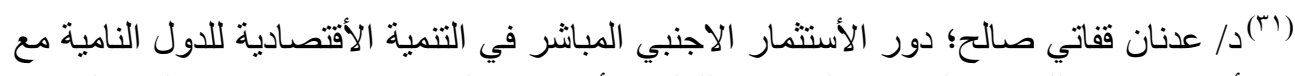

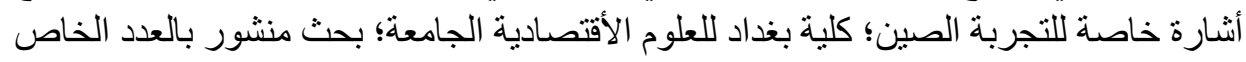

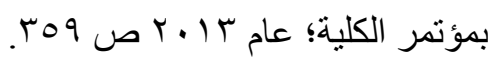

(r" للمزيد رجع أ/ حسان ضفر؛ الأستثمار الأجنبي المبانشر - تعاريف وقضايا - بحث سابق ص؟؟.

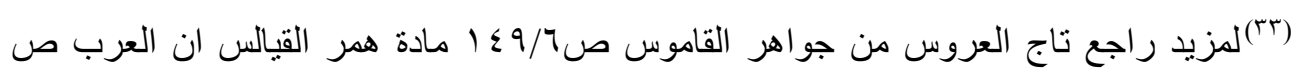

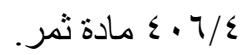

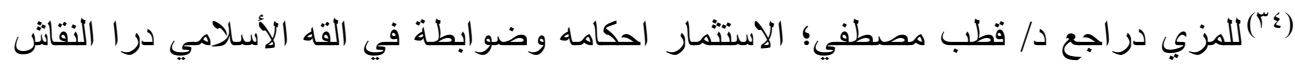

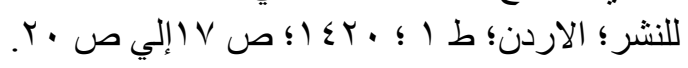

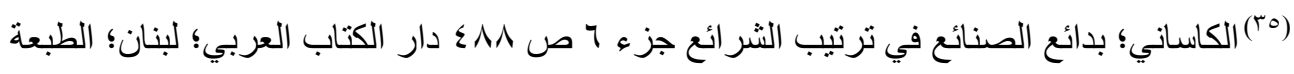

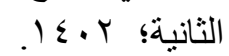

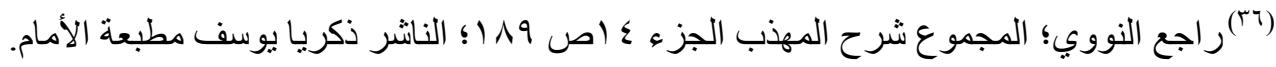

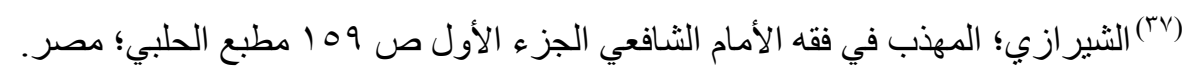
(†^) جون هدسون؛ ماركه مرقد؛ العلاقات الأقتصادية الدولية؛ تعريب طه منصورص 799.

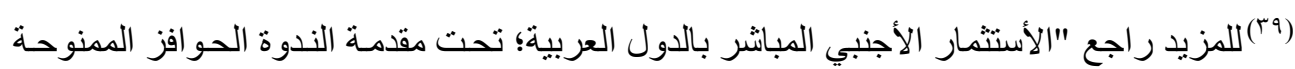

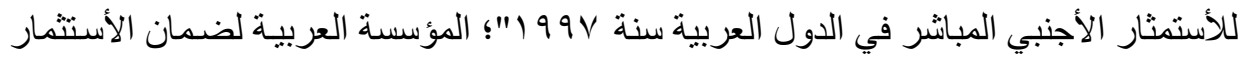

$$
\text { IVV ص }
$$

العدد الرابع الجزء الثاني 19 • ب

المجلد العانشر 
د/ تاهر عبد الغنلى ايوبه الهمك

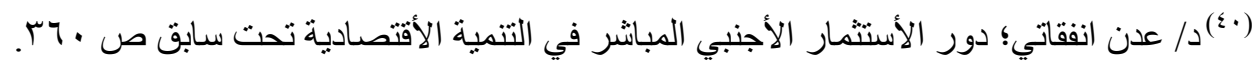

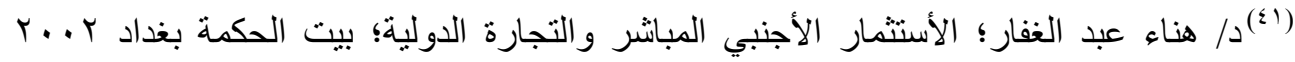
صها.

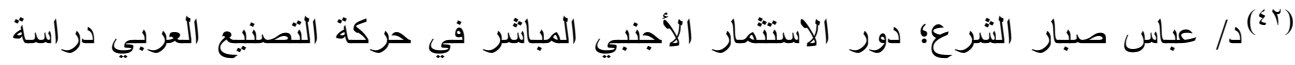

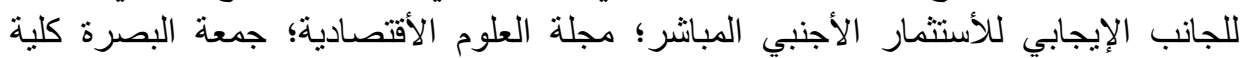

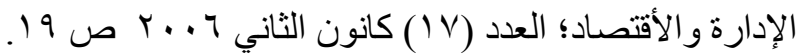

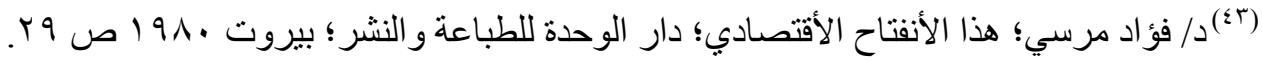

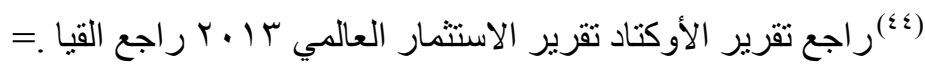

Unctad (2.13) wir ; fdi policies for development national and international perspectives; united nations geneva . 